\title{
EMBRYONIC STEM CELL RESEARCH AND RELIGION: THE BAN ON FEDERAL FUNDING AS A VIOLATION OF THE ESTABLISHMENT CLAUSE
}

\author{
Larry J. Pittman*
}

Table of Contents

I. Introduction . . . . . . . . . . . . . . . . . . 132

II. President Bush's Ban of Federal Funding of Embryonic Stem Cell Research and Religion ....................... 135

III. The Religious Opposition to Abortion and Stem Cell Research Is Both Misguided and A Violation of the Free Will Doctrine . . . . 138

IV. Violation of the Establishment Clause . . . . . . . . . . . . 155

A. Political Debate in a Pluralist Democracy ........... 155

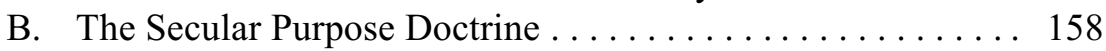

C. A Proposed Mixed Motive Test for Establishment Clause

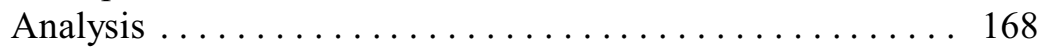

D. Some Applications of the Proposed Mixed Motive Standard ......................... 172

E. Applying the Mixed Motive Proposal to President Bush's

Ban on Embryonic Stem Cell Research . . . . . . . . . . 181

V. Conclusion ............................ 189

* Professor of Law, University of Mississippi School of Law. B.B.A. 1983, University of Mississippi; J.D. 1986, University of Mississippi School of Law; LLM. 1992, Harvard Law School. 


\section{INTRODUCTION}

Many Americans die each day from diseases affecting the heart, liver, kidneys, brain and a whole host of other bodily organs. Scientific researchers are constantly trying to develop new treatments for such medical conditions. Presently, the research community is working hard to develop medical treatments using stem cells from human embryos. ${ }^{1}$ That process involves extracting stem cells from either excess embryos that are no longer needed for in vitro fertilization ${ }^{2}$ or from embryos that are created through therapeutic cloning. ${ }^{3}$ At the blastocyst stage, about five days after the beginning of an embryo, researchers extract stem cells from the embryo and place them in a

1. The first isolation of embryonic stem cells from embryos was performed by James A. Thomson, a researcher at the University of Wisconsin, and by John D. Gearhart at John Hopkins University School of Medicine. Rick Weiss, A Crucial Human Cell Isolated, Multiplied, WASH. Post, Nov. 6, 1998, at A1.

2. Rick Weiss, The Power to Divide, NAT'L GeOGRAPHIC, July 2005, at 3, 12.

To obtain embryonic stem cells from excess embryos, embryos are allowed to divide in a clump of undifferentiated blastocyst cells that normally appears four or five days after fertilization of the female's egg. See generally Stem Cells: A Primer, National Institutes of Health, Sept. 2002, http:// www.travisroyfoundation.org/pages/pdf/NIH-Stemcells.pdf [hereinafter Stem Cells]. A researcher then extracts the blastocyst cells and places them into a petri dish where they are messaged with either chemicals or electroshock so that the cells will differentiate (morph) in to desired cells, such as heart cells, kidney cells, and brain cells. See id. Some researchers believe that after appropriate research has perfected the creation of embryonic stem cells that these undifferentiated stem cells can be injected into a human patient and that the cells will produce the cells and tissues that are needed to regenerate a patient's heart, kidney, brain and other organs. See id. The hope is that these stem cells will cure heart diseases, kidney diseases, and such brain defects as Alzheimer and Parkinson diseases. See id.

3. When stem cells are created through the therapeutic cloning process ("somatic cell nuclear transfer cloning"), the nucleus of a female's egg is removed and replaced with the nucleus from a human skin cell or from another donor site. Cloning and the Future of Human Embryo Research 9 (Paul Lauritzen ed., 2001). Human skin cells are commonly believed to be an appropriate source of cells that can be injected into a female's egg. Human Cloning: Science Fiction or Reality?, http://www.bioteach.ubc.ca/ Biomedicine/HumanCloning. The resulting embryo will have only the donor's DNA genetic code, and not the female egg donor's code, which was taken out when the nucleus of the egg was removed. CLONING AND the Future of Human Embryo Research 9 (Paul Lauritzen ed., 2001); Human Cloning: Science Fiction or Reality?, http://www.bioteach.ubc.ca/Biomedicine/HumanCloning. The combining of the donor's cell with the female's egg will create an embryo that has the potential, if not destroyed during the extraction of embryonic stem cells, to grow into a cloned human with the same genetic make up as the donor of the human skin cells. See id. at 9.

However, as with the extraction of embryonic stem cells from human embryos created during the in vitro fertilization process, the embryos that researchers create during therapeutic cloning are destroyed at the blastocyst stage, when researchers remove undifferentiated stem cells so that medical personnel can use them to create desired human cells and tissues. Carla Garnell, "Nature's Repair Shop"-Promise, Science of Stem Cell Research Explored, National Institutes of Health, http://www.NIH.gov/news/NIH-Record/ 02_08_200/story02.htm ("when you separate the inner cell mass from the blastocyst, you are destroying that embryo"); see generally Stem Cells, supra note 2. 
petri dish where the cells divide to produce a line of millions of stem cells. These stem cells are undifferentiated, meaning that they are still capable of transforming themselves into many different types of cells that exist in the human body. The hope is that physicians and other medical personnel will one day be able to inject these stem cells into a patient's diseased heart, kidney, brain, liver, spinal cord or other organ, and the stem cells will transform themselves into the same type of cells that comprise the host organ. ${ }^{4}$ The expectation is that the stem cells will repair the patient's heart or other organs by curing diseases and otherwise improving the patient's medical condition and life expectancy. ${ }^{5}$

The only problem is that embryonic stem cell research is controversial because the embryos from which the researchers extract stem cells are destroyed during the extraction process. ${ }^{6}$ Some religious groups believe that the destruction of the embryos is immoral because embryos, even at the fiveday developmental stage, have the same value as post-birth humans. In other words, these groups believe that human life and existence of the soul begin at the conception of an embryo during the initial fertilization process. ${ }^{7}$ This belief is the same argument that some religious groups use to oppose abortions. ${ }^{8}$ Of course, as with abortions, the embryonic stem cell research issue has become eminently more complicated as different groups, those who oppose the research and those who favor it, have politicized the issue in their efforts to convince the federal government to either permit or oppose federal funding of embryonic stem cell research. ${ }^{9}$

The political debate over federal funding of embryonic stem cell research came to a crucial junction on August 9, 2001, when President Bush issued an executive order barring federal funding of research on new lines of embryonic

4. Shelley Livaudais, The Stem Cell Debate, May 19, 2005, http://www.myboot.com/articles/p0121-the-stem-cell-debate.html.

5. Weiss, supra note 2, at 3 .

6. See id.

7. Master, Not Product of Technology, July 23, 2001, http://www.geocities.com/seapadre_1999/ stemcellresearch-pope.html.

8. Frist Backs Stem Cell Research, Angers Abortion Foes, July 29, 2005, http://www.cnn.com/ 2005/POLITICS/07/29/frist.stem.cells.ap/.

9. The federal government funds most scientific and medical research in this country. Without federal financing, there would not be enough money for such research, nor would there be the type of quality control and federal regulation that some believe is necessary to ensure that the research adheres to acceptable standards. Keith R. Yamamoto, Bankrolling Stem-Cell Research with California Dollars, 351 New Eng. J. Med. 1711-13 (2004) (asserting that "[t] he only possible source for adequate support of our medical schools and medical research is the taxing power of the Federal Government"). 
stem cells that researchers develop after August 9, 2001. ${ }^{10}$ The President apparently believed that the approximately sixty lines of then existing embryonic stem cells would be a sufficient source for embryonic stem cell research. ${ }^{11}$ However, the current belief is that only approximately twenty lines of existing embryonic stem cells are available for research because the other lines are either infected with mouse viruses or are otherwise unfit for research. ${ }^{12}$ Some commentators believe that researchers need additional lines of stem cells and that there should be federal funding of research on new lines of cells. ${ }^{13}$ Some believe that without federal funding the United States will fall behind South Korea, the United Kingdom and other countries that allow governmental funding of various types of embryonic stem cell research. It would be ironic if this were to happen given that researchers in the United States discovered the embryonic stem cell research process. ${ }^{14}$

The United States Congress is presently involved in the debate over federal funding. The House of Representatives has passed a bill that would allow federal funding of embryonic stem cell research, and there is growing support for a similar bill in the Senate. ${ }^{15}$ However, President Bush has threatened to veto any law that Congress passes to authorize federal funding of new lines of stem cells. ${ }^{16}$

Part II of this Article discusses President Bush's August 9, 2001, ban on federal funding of future lines of embryonic stem cell research and asserts that his religious beliefs are the only real reason for the ban. Part III explains the connection between the religious arguments against abortion and embryonic

10. Press Release, The White House, Office of the Press Secretary, President Discusses Stem Cell Research (Aug. 9, 2001) available at http://www.whitehouse.gov/news/releases/2001/08/20010809-2.html.

11. See id.

12. George Q. Daley, Missed Opportunities in Embryonic Stem-Cell Research, 351 New Eng. J. MED. 627 (2004) (stating that the existing federal funding available for embryonic stem cell lines "were cultured in contact with mouse cells and bovine serum, which renders them inferior to newer lines (derived under pristine conditions) for potential therapeutic applications.").

13. Jeffrey M. Drazen, Embryonic Stem-Cell Research-The Case for Federal Funding, 351 New ENG. J. MED. 1789 (2004) (asserting that "[i]f we continue to prevent federal funds from being used to support this research in the United States, the ability of our biomedical scientists to compete with other research teams throughout the world will be undermined").

14. Weiss, supra note 2, at 17, 22.

15. Emily Heil, House Bucks GOP Leaders, Backs Embryonic Stem-Cell Bill, CONGRESS DAILY AM, May 25, 2005, at 7.

16. See id. In opposition to the House-passed bill, President Bush threatened to veto the bill, saying the legislation would "compel all American taxpayers to be used to encourage the ongoing destruction of human life." Id. It seems logical that the President's statement shows that his opposition to the House bill, and to embryonic stem cell research, is based upon a religious belief that life begins at the point of conception as reflected in his reference to the "destruction of human life." 
stem cell research, concluding that the same religious beliefs support the opposition of both of these practices. This part further asserts that the opposition is not well-grounded because there are no biblical verses that decisively show that God opposes abortions and embryonic stem cell research. This section concludes that any attempt by the religious right and President Bush to oppose abortion and embryonic stem cell research is a violation of God's free will doctrine.

Part IV and its subparts assert that President Bush's ban on federal funding of embryonic stem cell research is a violation of the Establishment Clause. The arguments presented therein include an analysis of the Court's Establishment Clause jurisprudence. Importantly, this section proposes a new mixed motive test that the Court should adopt when applying the Establishment Clause to a challenged legislative enactment. That is, as with an Equal Protection challenge under the Fourteenth Amendment, the proponent of a challenged law should have the burden of persuasion of showing that a governmental entity would have adopted the challenged law even if there had been no religious purpose supporting the law.

This section applies the proposed mixed motive test to the Hyde Amendment that banned the federal funding of elective abortions and concludes that one can make a strong argument that that Amendment violates the Establishment Clause. The section also applies the proposed mixed motive test to President Bush's August 9, 2001 ban on federal funding of embryonic stem cell research and shows that the ban is an unconstitutional violation of the Establishment Clause.

\section{President Bush's Ban of Federal Funding of Embryonic Stem Cell Research and Religion}

Despite religious arguments against stem cell research, ${ }^{17}$ a substantial

17. Some opponents of embryonic stem cell research have looked towards adult stem cells as a possible alternative source of stem cells for treatment of the same medical conditions. Recent studies have shown that, in both mice and human, adult bone marrow stem cells have differentiated into cartilage cells, kidney cells, liver cells, heart cells, and lung tissue cells. David A. Prentice, Adult Stem Cells, 19 Issues In Law And MEdicine 265, 269-70 (2004); Gabe Romain, Marrow Stem Cells Make Liver Rather Than Fusing With Existing Cells, They Help Regenerate Organ When Exposed to Damaged Tissue, Better HumANS (June 3, 2004) (showing that adult bone marrow stem cells have differentiated into liver cells and when injected into a mouse with a liver injury were able to restore liver function.); Posting of BJS, Cells From Adult Bone Marrow Can Be Converted Into Brain Stem Cells, http://www.scienceblog.com/ cms/node/2680 (Apr. 29, 2004, 14:00 EST) (bone marrow stems cells differentiated into brain stems cells); Jiang Yuehua et al., Pluripotency of Mesenchymal Stem Cells Derived From Adult Marrow, 416 NATURE 
majority of Americans across all political parties, religious groups, racial groups, and political ideologies supports embryonic stem cell research and the federal funding of such research. ${ }^{18}$ Only a minority of Americans, primarily

41 (2002) (adult mice stem cells differentiated into liver, lung, and gut cells when injected into mice embryos).

But some doubt that adult stem cells have the same plasticity as embryonic stem cells. Doubt Cast on Adult Stem-Cell Plasticity Studies, Howard Hughes Medical Institute, Oct. 12, 2003, http:// www.hhmi.org/news/pdf/morrison3.pdf. In other words, instead of believing that adult stem cells actually evolve into different types of stem cells, some believe that adult stem cells fuse with the tissue cells into which they are implanted and that such cells simply join with those tissue cells instead of changing into the same types of tissue cells. See id. Other studies show that adult bone marrow stem cells do not transdifferentiate into heart muscle but simply fuse with existing muscle tissue. Gabe Romain, Adult Stem Cell Heart Repair Questioned: Discovery A Setback in Search for Alternative to Embryonic Cell Source, Better Humans (June 3, 2004); Leora B. Balsam et al., Haematopoietic Stem Cells Adopt Mature Haematopoietic Fates in Ischaemic Myocardium, 428 NATURE 670, 688 (2004); Clarks E. Murry et al., Haematopoietic Stem Cells Do Not Transdifferentiate Into Cardiac Myocytes in Myocardial Infarcts, 428 NATURE 664, 665 (2004). For a discussion of whether adult stem cells can transdifferentiate into different types of tissues and cells, see Suzanne Kadereit, The Plasticity of Stem Cell Plasticity, Int'1 Soc'y for Stem Cell Research, Apr. 21 2004, http://isscr.org/scientists/TOM/printversions_archive/TOM_Apr_04.pdf.

The fear is that fused cells will not be as efficacious as would embryonic stem cells that some believe can fully differentiate into many different types of cells. However, there might be some medical benefits from the fusion of bone marrow stem cells with certain existing tissue. In one study, researchers discovered that adult mouse bone marrow stem cells can create new liver tissue through fusion with mice liver cells instead of "transdetermination mechanism." George Vassilopoulos et al., Transplanted Bone Marrow Regenerates Liver By Cell Fusion, 422 NAture 901-04 (2003); Xin Wang, Cell Fusion is the Principal Source of bone-Marrow-Derived Heptocytes, 422 NATURE 897 (2003). More research probably needs to be done to measure the health benefits of fused cells.

Despite the uncertainty over whether adult stem cells can differentiate or change into different types of cells and tissue, the U.S. Food and Drug Administration has approved at least one human clinical trial in which a researcher in Houston, Texas will inject into patients' heart muscles their own adult bone marrow stem cells with the hope that the stem cells will differentiate into new heart muscle tissue and treat the injured or diseased hearts. Nancy Touchette, Bone Marrow Stem Cell Trial Approved for Heart Patients, Genome News Network, Apr. 16, 2004, http://www.genomenewsnetwork.org/articles/ 2004/04/16/stem_cell_trial.php.

The debate over whether adult stem cells can differentiate into different types of tissues and cells is important because if they can, then some argue that there would be no need to use embryonic stem cells. Opponents of Embryonic Stem Cell Research Herald Preliminary Discovery of 'Highly Versatile' Adult Stem Cells, The Henry J. Kaiser Family Foundation, Jan. 25, 2002, http://www.kaisernetwork.org/ Daily_reports/rep_index.cfm?DR_ID=9137. If adult stem cells are found to have the save type of regenerative capacity as embryonic stem cells, then embryos do not have to be destroyed to obtain stem cells. See id. But given the uncertainty over the transdifferentiation of adult stem cells, some researchers believe that it is better to continue embryonic stem cell research. Frequently Asked Questions, Do Adult Stem Cells Have the Same Capability as Embryonic Stem Cells?, Stem Cell Research Foundation, http:// www.stemcellresearchfoundation.org/About/FAQ.htm. Furthermore, even if researchers prove adult stem cells to be just as beneficial as embryonic stem cells, the refusal to use embryonic stem cells because of religious opposition against embryonic stem cell research would still be a violation of the Establishment Clause as discussed in this Article. See infra Part IV.E, notes 238-71.

18. Public opinion polls show that a majority of Americans, from all walks of life, are in favor of 
the leadership of certain religious organizations and a minority of their supporters, oppose this type of research. ${ }^{19}$ President Bush's August 9, 2001, ban on federal funding puts him within this minority and appears to be his attempt to keep the political support of the minority of evangelical Protestants and other pro-life supporters who oppose embryonic stem cell research.

This conclusion is appropriate because the President has not articulated any non religious reason for his opposition to federal funding. For example, his religious position is shown by his August 9, 2001, statement in support of the ban: "I also believe that human life is a sacred gift from our Creator. I worry about a culture that devalues life, and believe as your President I have an important obligation to foster and encourage respect for life in America and throughout the world." ${ }^{20}$ Just like the beliefs of some evangelicals and other conservative religious groups, such as the Roman Catholic Church, the President apparently believes that human embryos, even the ones that are less than five days old, deserve the full array of protections as if they were post-

Embryonic Stem Cell research. A June 2004 Opinion Research Corp. opinion poll shows that " $[\mathrm{b}] \mathrm{y}$ more than a 2-1 margin (60\%-26\%), Americans support medical research that uses stem cells from human embryos." Opinion Research Corp., American Views on Stem Cell Research In the Wake of the DeAth OF Ronald REAGAN (2004), http://www.resultsforamerica.org/calendar/files/ RstemcellresearchTopline.pdf. This percentage of support increased when the researchers gave more information about the medical benefits that might be possible because of embryonic stem cell research, increasing to $72 \%$ for and $23 \%$ against the research. Id. Even when informed that research derives embryonic stem cells through a process that kills embryos, $73 \%$ of those polled still favored the research, while only $24 \%$ were against such research. See id.

Additionally, the June 2004 polls shows that conservatives supported embryonic stem cell research $47 \%$ to $38 \%$, and that $67 \%$ of moderates and $75 \%$ of liberals supported the research. Id. Interestingly, $46 \%$ of evangelical/fundamentalist Christians supported embryonic stem cell research, while only $40 \%$ opposed it. Id. The percentage of conservative support increased to $60 \%$, and the percentage of evangelicals/fundamentalists increased to $59 \%$, when pollsters informed these groups of the medical benefits that might flow from embryonic stem cell research. Id. With such medical benefit information, "at least two in three Americans in all demographic groups" supported embryonic stem cell research. Id. Not only did a substantial majority of Americans support the research, $74 \%$ to $22 \%$ of those who responded to the poll supported federal funding of this type of research, including $62 \%$ of conservatives and $65 \%$ of evangelicals/fundamentalists, along with $88 \%$ of liberals and $80 \%$ of moderates. Id. The researchers concluded that "[s]upport for stem cell research is rapidly approaching bipartisan status." Id.

Substantial public support in favor of both embryonic stem cell research and the federal funding of such research existed before President Bush's August 9, 2001 ban on federal funding of future lines of stem cell research. For example, a 2001 poll showed that a majority of Americans, including Roman Catholic, white evangelical protestants, independent voters, moderates, and pro-choice advocates were in favor of stem cell research, while half of pro-life advocates were opposed to such research. Gary Langer, Public Backs Stem Cell Research - Most Say Government Should Fund Use of Embryos, ABCNEws/BeLIEFNET PoLL, June 26, 2001, http://www.abcnews.go.com/sections/politics/DailyNews/poll010626.html.

19. See supra note 18 and accompanying text.

20. George W. Bush, Pres. of U.S., Remarks by the President on Stem Cell Research (Aug. 9, 2001), 2001 WL 896981 at *3-*4. 
birth humans. ${ }^{21}$ In this respect, the President's ban is consistent with the views of some right-wing religious groups that even a tiny human embryo is a child that is created by God in his own image:

To argue that "surplus" embryos may be thrown away in any case arrogantly glosses over the fact that embryos are living human beings, created in the image of God and deserving protection. They are tiny boys and girls with complete genetic codes, not spare parts for medical experiments. To propose creating human embryos solely for scientific benefit and then destruction is unspeakably evil. ${ }^{22}$

It is important to note that in his August 9, 2001 statement explaining the no federal funding policy, the President did not make any allegations that future federal funding of embryonic stem cell research poses any type of harm to post-birth humans, ${ }^{23}$ because there is no medical evidence to support such a claim. Other than his belief in the sanctity of embryos as humans from the moment of conception, ${ }^{24}$ there is no logical explanation for the August 9, 2001 ban. Therefore, the ban, premised on the President's efforts to promote religious doctrine regarding the source of and the sanctity of human life, presents substantial Establishment Clause problems, as argued below. ${ }^{25}$

\section{The Religious Opposition to Abortion and Stem Cell Research \\ Is Both Misguided and A Violation of the Free Will Doctrine}

One might reasonably conclude that the current debate regarding embryonic stem cell research is just another feature of the efforts of some religious organizations to dictate and control reproductive issues in America. ${ }^{26}$ In other words, the organized religious opposition to embryonic stem cell research comes from the same religious groups that oppose abortions..$^{27}$ These

21. That an embryo is a human and desirous of the full range of protection given to other humans is a central tenet of religious groups that oppose both abortions and stem cell research. See infra note 239 and accompanying text.

22. Carrie Gordon Earll, Stem Cell Research: Truth vs. Hype, Focus on the Family Mag., 2001, http://www.family.org/fofmag/sl/a0024064.cfm.

23. See generally Bush, supra note 20.

24. See id.

25. See infra Part IVE notes 238-71.

26. U.S.CONST. amend. I; see also Lemon v. Kurtzman, 403 U.S. 602, 612-13 (1971) (asserting that a legislative enactment must be supported by a secular purpose).

27. Frist Backs Stem Cell Research, Angers Abortion Foes, July 24, 2005, http://www.cnn.com/ 2005/POLITICS/07/29/frist.stem.cells.ap/ (“'He [U.S. Senator Bill Frist] cannot be pro-life and proembryonic stem cell funding,' said Rev. Patrick J. Mahoney, director of the Christian Defense Coalition. 'Nor can he turn around and expect widespread endorsement from the pro-life community if he should 
opponents believe that, as with abortions, the embryos destroyed in embryonic stem cell research are fully human at the point of conception ${ }^{28}$ and that the destruction of such embryos is immoral under God's law. ${ }^{29}$ When considered in that context, the Establishment Clause issue becomes clearer.

The central religious argument against abortion and stem cell research is that an embryo after conception is the moral equivalent of a post-birth human. ${ }^{30}$ Therefore, some religious groups oppose abortion even if the pregnancy stems from rape or when the abortion would end a pregnancy that endangers the mother's life. ${ }^{31}$ Other religious groups are more lenient and would tolerate abortion for rape and the mother's health. ${ }^{32}$ Similarly, some

decide to run for president."'); Rachel Benson Gold, Embryonic Stem Cell Research-Old Controversy; New Debate, 7 The GutTmacher Report on Public Policy 4 (2004), available at http://guttmacher.org/pubs/ tgr/07/4/gr070404.html ("an enduring controversy over work that is portrayed by its proponents as holding immense scientific promise and by its opponents as devaluing human life in its most basic form").

28. Thomas A. Shannon, Stem-Cell Research-How Catholic Ethics Guide Us, Catholic Update (American Catholic), Jan. 2002, available at http://www.americancatholic.org/newsletters/cu/ac0102.asp ("These claims are reflective of the traditional teaching recently restated, for example, in the Instruction from the Congregation for the Doctrine of the Faith, Donum Vitae, that the "human being is to be respected and treated as a person from the moment of conception and therefore from that same moment his rights as a person must be recognized."”).

29. See id. At least one commentator has described the Roman Catholic Church's view as follows:

Finally, for use of the research to be immoral, the act of destroying a blastocyst must itself be immoral. If one follows the line of reasoning that the blastocyst is not yet an individual and, therefore, not yet a person, its killing would certainly be a disvalue but would not be a moral evil having the equivalence of murder. Thus individuals would be able to use the clinical products that come from such research.

Such reasoning would be unacceptable to the teaching of, for example, Donum Vitae or the encyclical letter of John Paul II Evangelium Vitae. The basis for rejecting such procedures is the recognition of the human embryo's being accepted as a full human person from the moment of conception and, therefore, having an intrinsic dignity and value that cannot be compromised in the name of other values.

Id.

30. See ReligiousTolerance.org, Current Roman Catholic Teachings on Abortion, http:// www.religioustolerance.org/abo_hist_c.htm (last visited May 23, 2006) [hereinafter Teachings on Abortion].

31. See id

32. ReligiousTolerance.org, When Does Human Personhood Begin? Belief 4: Jewish Beliefs, http://www.religioustolerance.org/jud_abor.htm (last visited May 23, 2006); Rabbi Raymond A. Zwern \& Rabbi Richard J. Shapiro, Religious Coalition for Reproductive Choice, Abortion: Perspectives from Jewish Traditions, Educational Series No. 5; МетноDist CHurch, http://www.biblebelievers.net/ Apostasy/kjcmethd.htm (last visited May 23, 2006); The Religious Coalition for Reproductive Choice is a national organization comprised of approximate forty religious dominations that support a woman's right to make reproductive choices whether to have abortions. Call to Justice, Religious Coalition for Reproductive Choice, http://www.rcrc.org/.

Although it is true that organized religious sentiment against abortion varies from one denomination to another, the Roman Catholic Church appears to be the most dogmatic in its opposition against all forms 
religious groups oppose stem cell research because they believe that the embryo is fully human at the point of conception, while other religious entities do not oppose such research because they do not believe that embryos are the moral equivalent of post-birth humans. ${ }^{33}$ This debate about abortions and embryonic stem cell research implicates the Establishment Clause in at least two respects. First, arguments regarding when life begins and the sanctity of life normally are premised on the existence of God and His intent regarding human life. Second, the fact that different religious organizations have different opinions about the beginning of and the sanctity of life shows that there is no religious consensus on the abortion and stem cell research issues. Therefore, President Bush's ban on federal funding of embryonic stem cell research, premised upon his religious belief in the sanctity of life in all forms even at the embryonic stage, means that he has chosen one set of religious views over a different set of views about the sanctity of life and the morality of embryonic stem cell research. The interjection of his religious views into the embryonic stem cell debate, and his choosing of one set of religious beliefs over other beliefs to support his ban, presents a significant Establishment clause issue. ${ }^{34}$

of abortion, including abortions because of rape and for the protection of a woman's health. ReligiousTolerance.org, Abortion: Current Beliefs by Various Religious and Secular Groups, http://www.religioustolerance.org/abo_hist1.htm (last visited May 23, 2006). The Southern Baptist Convention holds similar views against all abortions for all reasons, as does the Presbyterian Church in America, and the Assemblies of God. Other religious groups hold similar views. See id.

In contrast, the United Methodist Church does not oppose an abortion when done for the purpose of saving the mother's life. See id. Other denominations are not against abortion if the mother's life or health are seriously in danger. See id. And, Judaism believes that abortions are permissible to save the mother's health or life. See id. Even when some denominations would limit abortions to saving the mother's life and health, such denominations would not outlaw abortions when performed for birth control or other aesthetic reasons. See id.

33. Perspectives: Religious Views on Stem Cell Research, Religion and Ethics Newsweekly, July 27, 2001, http://www.pbs.org/wnet/religionandethics/week448/perspectives.htm (asserting that the Roman Catholic Church and the Southem Baptist Convention oppose stem cell research because of the moral value that they place on the embryo, while the Presbyterian Church USA and the Union of Orthodox Jewish Congregations do not oppose the research because they believe that the embryo does not have the full moral status as a post-birth person).

34. County of Allegheny v. ACLU Greater Pittsburgh Chapter, 492 U.S. 573, 591 (asserting that "[n]either a state nor the Federal Government can ... prefer one religion over another."). Scholars have opined that the opposition to abortion is based upon a religious belief. Vincene Verdun, If the Shoe Fits, Wear It: An Analysis of Raparationsto African American, 67 TuL. L. Rev. 597, 609 (1993) ("For example, the underlying normative difference in the abortion debate between pro-choice and pro-life advocates is the belief by pro-life advocates that abortion is sinful or wrong - a belief that is usually grounded in religious or biblical principles so deeply imbedded in the perception of the believer that there is no room for compromise."); Daniel A. Faber, Legal Pragmatism and the Constitution, 72 MinN. L. REv. 1331, 1370 (1988) ("Moreover, much of the opposition;9654;9654 to abortion;9656;9656 stems from highly organized, 
Even if there were no violation of the Establishment Clause, it would still be unwise to ban either abortions or embryonic stem cell research given that there is no convincing biblical authority that establishes that abortions and stem cell research are immoral. Those who rely upon biblical verses to either support or oppose such practices are mostly speculating about God's intent on these issues. A brief review of several of the more popular biblical verses shows the inherent fallacy of relying upon the bible as support in these areas of the law.

Some rely upon specific statements by God, including Exodus 21:22-23, Numbers 5:11-21 and the Sixth Commandment. ${ }^{35}$ A closer examination shows that these verses are too vague, confusing, and incomplete to establish God's opinion for or against abortions and embryonic stem cell research. Exodus 21:21-23 is so malleable that one can use it to either support or oppose abortion, ${ }^{36}$ a duality that is enhanced by different versions of the bible containing different language that allows varied interpretations. ${ }^{37}$ Some of

intense pressure based on sectarian religious beliefs"). The same conclusion applies to the opposition to embryonic stem cell research which is based upon the same religious belief that the moral value of an embryo is the equivalent of the moral value of a post-birth human. Therefore, a government violates the Establishment Clause when it bases such public policy decisions as the federal funding of stem cell research on the religious beliefs of those who oppose this type of research. See infra notes 238-69. The violation exists because the government would have chosen a religious belief over an opposing secular belief in favor of such research.

35. See generally Abortion and the Bible, http://www.abortion-and-bible.com(last visited May 23, 2006) (discussing numerous bible verses in opposition to abortion).

36. Exodus 21:22-23 (King James).

37. The old King James Version contains the following version: "If men strive, and hurt a woman with child, so that her fruit depart from her, and yet not mischief follow: he shall be surely punished, according as the woman's husband will lay upon him; and he shall pay as the judges determine." Exodus 22 (King James).

The New King James Version provides:

If men fight, and hurt a woman with child, so that she gives birth prematurely, yet no harm follows, he shall surely be punished accordingly as the woman's husband imposes on him; and he shall pay as the judges determine. But if any lasting harm follows, then you shall give life for life, eye for eye, tooth for tooth, hand for hand, foot for foot, burn for burn, wound for wound, stripe for stripe.

Exodus 21:22-25 (New King James).

The New International Version's language, in part, states:

If men who are fighting hit a pregnant woman and she gives birth prematurely but there is no serious injury, the offender must be fined whatever the woman's husband demands and the court allows. But if there is serious injury, you are to take life for life. .

Exodus 21:22 (New International Version).

In describing the inconsistency in language between different versions of the bible, one writer states:

This passage has been mistranslated in some versions. For example, some versions use the word "miscarriage" instead of translating the Hebrew phrase literally "so that her children come out." The text is envisioning a situation in which two brawling men accidentally injure a 
those who support the right to an abortion rely upon the phrase "so that her fruit departs from her" to indicate that one who hits a pregnant woman and causes her fetus to be discharged (in an injured or dead state) shall be subject to only a monetary penalty for the injury to or the death of the child, but shall be subject to the death penalty for killing the mother in the same incident. ${ }^{38}$

These pro-choice supporters believe that Exodus 21:23 establishes that the life of the fetus and the life of the mother have different values, in that a tortfeasor must pay only a monetary penalty if he accidentally or intentionally kills an unborn fetus but must be subject to death for accidentally or intentionally killing the mother. ${ }^{39}$ The gist of this argument is that the biblical prohibition against murder does not apply to an unborn fetus, but is applicable only to children and adults after their birth from the mother. ${ }^{40}$ Some contend that Exodus 21:22-23 is consistent with Judaism's belief that a fetus is a full human person only after birth, ${ }^{41}$ and therefore, it is permissible for a woman to have an abortion especially to protect her health and safety. ${ }^{42}$

In contrast, some pro-life believers have a different interpretation. They believe that if only a miscarriage occurs and the fetus is not injured, the perpetrator shall pay a fine to the mother's husband. ${ }^{43}$ But if the fetus is killed or injured during the miscarriage, the punishment for the fetus' injury or death is the same as for the mother's injury or death. ${ }^{44}$ As such, pro-life supporters contend that the fetus has the same status or value as the mother, which they believe is support against abortion. ${ }^{45}$

pregnant bystander. The injury causes the woman to go into early labor, resulting in a premature birth of her child. If neither the woman nor the child is harmed, then the Law of Moses levied a fine against the one who caused the premature birth. But if injury or even death resulted from the brawl, then the law imposed a parallel punishment: if the premature baby died, the one who caused the premature birth was to be executed - life for life. This passage clearly considers the pre-born infant to be a human being, and to cause a pre-born infant's death was homicide under the Old Testament-homicide punishable by death.

Dave Miller, Abortion and the Bible (2003), http://www.apologeticspress.org/articles/1964.

38. Libchrist.com, Biblical Overview of Abortion Issue, http://www.libchrist.com/other/abortion/ overview.html (last visited May 23, 2006) (citing bible verse that have been used in arguments against and in support of abortion).

39. See id.

40. See id.

41. See id.

42. See id.

43. Miller, supra note 37.

44. Id.

45. One pro-life organization describes Exodus 21:22-25 as follows:

When understood as a reference to miscarriage, Exodus 21:22-25 is sometimes used as evidence that the unborn is subhuman. But a proper understanding of the passage shows reference is not to a miscarriage, but to a premature birth, and that the "injury" referred to, which is to be 
The same type of inconsistent interpretations can be made of other verses that contain direct statements by God, including Numbers 5:11-28 which discusses God's instruction to Moses on how a jealous husband can test the faithfulness of his wife:

[W] hen he hath made her to drink the water, then it shall come to pass, that, if she be defiled, and have done trespass against her husband, that the water that causeth the curse shall enter into her, and become bitter, and her belly shall swell, and her thigh shall rot: and the woman shall be a curse among her people. ${ }^{46}$

Some pro-choice supporters have cited this verse as God's support for an abortion when a woman has committed adultery. ${ }^{47}$ They believe that the swelling of the belly and the rotting of the thigh would cause a miscarriage of the fetus if the woman were pregnant. ${ }^{48}$ Hence, they believe that, in some circumstances, even God believed in abortion. ${ }^{49}$ On the other hand, pro-life supporters assert that the verse does not support abortion because it does not state whether the woman is pregnant. ${ }^{50}$ These conflicting interpretations of Numbers 5:11-23 show that the meaning of the verse is not clear. The prochoice interpretation is not entirely implausible, given that some believe that the foul water curse could cause the death of an adulterous woman's fetus if she were pregnant. ${ }^{51}$

The Sixth Commandment, another direct statement from God, provides that "Thou Shall Not Kill." 52 Pro-life supporters believe that this commandment proscribes the murdering of fetuses whom they believe receive

compensated for like all other injuries, applies to the child as well as to his mother. This means that, "far from justifying permissive abortion, in fact grants the unborn child a status in the eyes of the law equal to the mother's."

ChristianAnswers.net, Abortion in the Bible and Church History, http://www.christiananswers.net/qeden/edn-abortioninthebible.html (last visited May 23, 2006). See also GodandScience.org, The Bible and Abortion: The Biblical Basis for a Prolife Position, http://www.godandscience.org/doctine/prolife.html (last visited May 23, 2006) [hereinafter Biblical Basis for a Prolife Position] (asserting that "[f]or all practical purposes, from a biblical perspective, abortion at any point must be considered murder by Biblebelieving Christians").

46. Numbers 5:22 (King James).

47. ReligiousTolerance.org, Passages in the Hebrew Scriptures (Old Testament) That May Deal With Abortion, http://www.religioustolerance.org/abo_biblh.htm (last visited May 23, 2006) [hereinafter Passages] (asserting that "[i]f she were pregnant at this time, the curse would certainly induce an abortion. Yet nobody seems to have been concerned about the fate of any embryo or fetus that was present.").

48. See id.

49. See id.

50. See id.

51. Passages, supra note 47.

52. Exodus 20:13 (King James). 
a soul at the point of conception; therefore, they believe that the life of a fetus, as far as God is concerned, is just as valuable as any post-birth human. ${ }^{53}$

Contrarily, some pro-choice believers observe that the Sixth Commandment does not specifically state that it applies to fetuses that one might abort. ${ }^{54}$ These supporters believe that the commandment is applicable only to living humans who have been born. ${ }^{55}$ In contrast, some pro-life religions, such as the Roman Catholic Church, believe that the fetus is fully human at the point of conception, defined as the natural fertilization of female egg by the male sperm. They believe that a fetus has a "soul" at conception and is thus within the protection of the Sixth Commandment. ${ }^{56}$

Other verses where God speaks to various prophets are also instructive on this issue. Jeremiah 1:4-5 reflects a conversation between God and Jeremiah, where God states: "Before I formed thee in the belly I knew thee, and before thou camest forth out of the womb I sanctified thee, and I ordained thee a prophet unto the nations. ..." ${ }^{57}$ Some contend that this means that Jeremiah was a person in God's eyes at least at the point of conception. ${ }^{58}$ Others believe that this verse means only that, being omnipotent, God could have planned and foreseen Jeremiah's role as a prophet before Jeremiah was conceived, not that God meant that sperm and eggs that predate conception, and embryos after conception, are persons deserving of the same protection as a child after birth. ${ }^{59}$

53. Abortion and the Bible, supra note 35 .

54. What Does the BibleSay About Abortion?, http://www.gumbopages.com/fridge/abortion.txt (last visited May 23, 2006). Regarding killings in the bible, one pro-choice advocate states:

An honest reader must admit that the bible contradicts itself. "Thou shalt not kill" did not apply to many living, breathing human beings, including children, who are routinely massacred in the bible. The Mosaic law orders "Thou shalt kill" people for committing such crimes as cursing one's father or mother (Exodus 21:17), for being a stubborn son (Deuteronomy 21:18-21), for being a homosexual (Leviticus 20:13), or even for picking up sticks on the Sabbath (Numbers 15:32-35)! Far from protecting the sanctity of life, the bible promotes capital punishment for conduct which no civilized person or nation would regard as criminal. Id.

55. Passages, supra note 47 ("Since the writers of the Hebrew Scriptures and the tradition of the Jewish people regarded a human person as beginning at birth when the newborn first takes a breath, this verse would not apply to abortion.").

56. Teachings on Abortion, supra note 30.

57. Jeremiah 1:4-5 (King James).

58. Abortion and the Bible, supra note 35.

59. Passages, supra note 47 (asserting that "[t]he passage does not appear to be related to the morality of abortion or whether a fetus is human person . . . It merely seems to discuss how God had planned the life of Jeremiah the prophet, before he was even conceived."). 
Other statements by God are similarly subjected to conflicting interpretations. Genesis 25:22-23 provides:

\begin{abstract}
And Isaac intreated the LORD for his wife, because she was barren: and the LORD was intreated of him, and Rebekah his wife conceived. And the children struggled together within her; and she said, If it be so, why am I thus? And she went to inquire of the LORD. And the LORD said unto her, Two nations are in thy womb, and two manner of people shall be separated from thy bowels; and the one people shall be stronger than the other people; and the elder shall serve the younger. ${ }^{60}$
\end{abstract}

Some contend that the fact that God had plans for Issac's children before they were conceived implies that all life is important and deserves protection, including the life of a fetus. ${ }^{61}$ Others correctly note that, despite this verse's reference to Rebekah's fetuses developing into future nations, it does not establish that abortions are immoral. ${ }^{62}$ Simply because God has plans for a person's life before her conception does not mean that at the conception stage the person's life has the same value that it has after birth. ${ }^{63}$ At most, the verse establishes only that God can omnisciently see into the future. ${ }^{64}$ That a fetus might grow into a post-birth human if allowed to fully develop does not mean that God's intent is that a secular society must give a fetus the same moral and legal protections accorded to post-birth humans. ${ }^{65}$

The same conclusion applies to two other direct statements from God. In Isaiah 44:2, God states, "Thus saith the Lord that made thee, and formed thee from the womb, which will help thee; Fear not, O Jacob, my servant; and thou, Jesurun whom I have chosen." ${ }^{66}$ Similarly, in Isaiah 44:24, He asserts, "Thus saith the LORD, thy redeemer, and he that formed thee from the womb, I am the LORD that maketh all things. ..." ${ }^{67}$ These two verses from Isaiah do not clearly establish God's intent regarding abortions and embryonic stem cell research. A belief that God created human sperm and eggs (thereby allowing one to be formed in the womb) does not necessarily imply that a fetus has the same moral status in the eyes of God as does a post-birth human. At best these verses can be read only to mean that babies come from their mothers' wombs, in which they grow after conception, and at some point they become

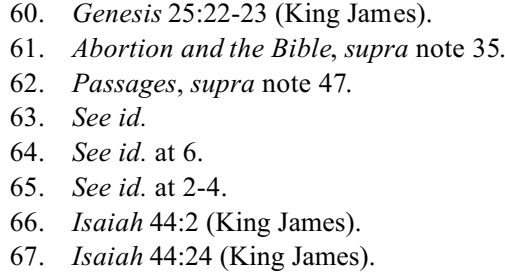


developed enough to be born and live outside of their mothers' bodies. These verses do not definitively show God's approval or disapproval of either embryonic stem cell research or abortions before a birth occurs.

This conclusion is not challenged by various biblical verses that are not direct statements by God. Statements from other biblical figures fail to conclusively establish God's position on these issues. Many of these verses involve statements of biblical figures about God's having formed a person while the person was in his mother's womb. For example, David's statement in Psalm 139:13-16 provides, "For thou didst form my inward parts, thou didst knit me together in my mother's womb. . . . Thy eyes beheld my unformed substance ...." Anti-abortion proponents believe that this verse supports the position that humans are persons from the point of conception, ${ }^{69}$ while prochoice supporters discount the verse as at best showing only God's control of the developmental stages of birth, and not His position on abortion. ${ }^{70}$ The most important reason that David's statement is not dispositive is that it is merely David's belief about God's role in creating him. The statement apparently expresses David's religious beliefs regarding his own creation and that of humans. It is not a direct statement of God's intentions or opinions about abortions or embryonic stem cell research. Even if David's statement that God creates every human in the mother's womb is true, and God can foresee one's future existence even before conception and throughout one's development in the womb, the statement does not establish that God desires that fetuses have the same moral value or status throughout the various stages of development. Nor does that verse show God's opinion about abortions and embryonic stem cell research.

David's statement in Psalm 139:13-16 shows the confusing and conflicting nature of different bible verses, ${ }^{71}$ especially when one considers it in light of the statements in Exodus 21:21-23 (which create confusion as to whether an accidentally killed fetus has the same moral value as the mother). All of the aforementioned conclusions regarding Psalm 139:13-16 apply to David's statements in Psalms 22:9: "But thou art he that took me out of the womb: thou didst make me hope when I was upon my mother's breasts." ${ }^{972}$

68. Psalm 139:13-16 (Revised Standard).

69. Abortion and the Bible, supra note 35 , at 6 .

70. Passages, supra note 47, at 5.

71. See generally Abortion and the Bible, supra note 35. See also Brian Elroy McKinley, Why Abortion is Biblical, http://www.elroy.net/ehr/abortion/html (critiquing various biblical verse as not showing that abortions are immoral).

72. 2 Psalm 22:9 (King James). 
These conclusions also apply to verses by other speakers who express their views about God having formed them in the womb. ${ }^{73}$ These biblical speakers (who must have been aware that they were at some point inside of their mothers' wombs and who must have also believed that God made them) would think that He must have made them from the start of their existence in the womb, which would have been at the point of conception. ${ }^{74}$ But such beliefs are not definite enough to serve as a basis for outlawing either abortions or embryonic stem cell research because one should not logically conclude, from such vague statements of fallible human figures in the bible, that just because God makes it possible for conception to occur, that a five-day old embryo has the same moral status in the eyes of God as do post-birth humans.

The same conclusion is true for other biblical verses that some believe are anti-abortion. Some cite Luke 1:36-44 regarding Elizabeth's pregnancy with John the Baptist and her sister Mary's pregnancy with Jesus. ${ }^{75}$ The extraordinary thing about these verses is that John the Baptist is believed to have leaped in Elisabeth's womb when his mother came into the presence of Mary who was pregnant with Jesus. ${ }^{76}$ This leaping is believed to indicate that John, even as a six-month-old fetus, knew that he was in the presence of Jesus. ${ }^{77}$ The implication is that John was human enough to be aware and react to Jesus, which indicates to some that John was just as valuable to God as any living human. ${ }^{78}$ Some anti-abortion supporters believe that this verse shows that all life is important and that God's plans for John the Baptist's life and for Jesus' life show that God has a plan for all of our lives before we are born. ${ }^{79}$ As such, the anti-abortion supporters, who rely upon John's leaping in his mother's womb, think that all fetuses are human from the point of conception. ${ }^{80}$ However, some pro-choice believers note that it is not

73. For a list of verses containing similar statements about various persons being formed by God in the womb, see Biblical Basis for a Prolife Position, supra note 45 (citing various biblical verses that make references to God having formed certain persons in their mothers' womb).

74. It is reasonable to believe that David and other biblical figures probable did not know as much about human reproduction as is known today. They might not have known the exact mechanics of how a male's sperm joins with a female's egg to create an embryo which subsequently grows into a baby. As such, some of these figures might have thought that God was directly involved in creating the embryo. This belief might have been the motivation for their conclusion that God formed them in their mother's womb.

75. Luke 1:36-44 (King James).

76. Ray C. Stedman, What Price Abortion?, Feb. 14, 1973, http://www.pbc.org/library/files/ $\mathrm{html} / 3450 . \mathrm{html}$.

77. See id.

78. See id.

79. Abortion and the Bible, supra note 35 , at 7.

80. However, neither of these verses of scripture definitively shows that all abortions are immoral. 
uncommon for fetuses to move inside of their mothers' wombs. ${ }^{81}$ They correctly do not believe that John's leaping means that God is opposed to abortion. $^{82}$

On the other hand, some anti-abortion supporters emphasize that the verse calls the fetus the "baby" 83 without making a distinction between a fetus inside of the womb and a baby after birth. ${ }^{84}$ Therefore, they contend that this bible verse is evidence that a fetus is just as valuable as a post-birth baby. ${ }^{85}$ However, it seems logical that the mere fact that Mary and Elisabeth might have called their fetuses "baby" is simply an expression of their opinions, and it does not necessarily indicate that the fetus inside of the womb should have the same moral value as a child after birth. God never stated that fetuses should have the same moral value, and any such conclusion from his statements or from the ambiguous statements of others is mere speculation that is too indefinite to support a prohibition against either abortion or embryonic stem cell research.

One could go on for days citing ambiguous bible verses to support or oppose abortion and embryonic stem cell research. In support, Ezekiel 37:8-10 discusses how human bones were rejoined and human flesh grew onto the bones, but that the reconstructed bodies did not become living humans until they began to breathe. ${ }^{86}$ Similarly, Genesis 2:7 discusses that, even after God had formed Adam from dirt, Adam did not become "a living soul" until God breathed into Adam's nose. ${ }^{87}$ Some who rely upon these scriptures believe that fetuses do not have a human soul until they breathe on their own, outside of the mother's body. ${ }^{88}$

In opposition, some pro-life supporters cite scriptures that show how much God and Jesus love children, and hate those who murder those who are innocent, to oppose abortions because they believe that abortions are inconsistent with such love of children. ${ }^{89}$ Similarly, for the love of children,

\footnotetext{
One interpretation of the scriptures might be that God had a special purpose for John the Baptist's and Jesus' lives, given their role in the development of the Christian faith, that God played an active role in divinely causing Elizabeth's and Mary's pregnancies, and therefore God had more interest in their lives and might be more opposed to abortion regarding them than God would be regarding other pregnancies.

81. McKinley, supra note 71.

82. See id.

83. Miller, supra note 37.

84. See id.

85. See id.

86. Ezekiel 37:8-10 (King James).

87. Genesis 2:7 (King James).

88. Passages, supra note 47 , at 1 .

89. Abortion in the Bible and Church History, supra note 45.
} 
some pro-life advocates cite Luke 18:16 which states, "But Jesus called them unto him, and said, 'Suffer little children to come unto me, and forbid them not: for such is the kingdom of God." "90 For God's hatred of those who kill the innocent, some rely upon Exodus 23:7 which provides, "and the innocent and righteous slay thou not: for I will not justify the wicked." 91 Those who use these scriptures believe that, because of the love for children and hatred for those who spill innocent blood, God and Jesus would not condone the murdering, through abortion, of innocent fetuses that pro-life advocates believe are just as valuable as post-birth humans. ${ }^{92}$

On the other hand, those who support abortions rely upon scripture to argue that the Old Testament did not place too much value on the lives of some children, especially those scriptures that show a preference for the human sacrifice of the firstborn in Exodus 13:1-2 and Exodus 22:29.93 Other pro-choice supporters also rely upon verses regarding Judah's order that his pregnant daughter-in-law, Tamar, being pregnant without having a husband, be buried with her child because she was deemed to be a prostitute. ${ }^{94}$ Similarly, they cite Menahem's, King of Israel, order that fetuses be ripped out of the bellies of Tiphsah's women as punishment for that city's refusal to open the gate to the city. ${ }^{95}$ Other pro-choice supporters cite God's threat that, in Samaria, He would rip open pregnant women. ${ }^{96}$

Additionally, some pro-choice supporters cite such Old Testament biblical verses as Leviticus 27:6 which states that a "monetary value" should be put only on the life of a child who is at least one month old, ${ }^{97}$ and Numbers $3: 15$ that, for census purposes, the Jews should count only children who were at least one month old. ${ }^{98}$ These pro-choice supporters used these scriptures to show that even children who were already born did not have much value until after they reach one month of age..$^{99}$ When these two scriptures are considered along with some of the other scriptures that pro-choice supporters rely upon,

90. Luke 18:16 (King James). See also Abortion in the Bible and Church History, supra note 45, at 2; Psalm 127:3 (King James) ("Lo, children are an heritage of the Lord and the fruit of the womb is his reward.").

91. Exodus 23:7 (King James); Miller, supra note 37.

92. See Abortion in the Bible and Church History, supra note 45.

93. Passages, supra note 47 , at 2-3.

94. See id.

95. See id.

96. Passages, supra note 47.

97. See id.

98. See id.

99. See id. 
some draw the conclusion that a fetus does not have the same value as a postbirth human, and therefore, an abortion is not against God's will. ${ }^{100}$

However, as with the scriptures that show God's love for children and hatred for murders of the innocent, the above-referenced scriptures that arguably show less value for fetuses and for post-birth children do not specifically involve the abortion of fetuses. Therefore, any conclusions that such scriptures condone abortions are pure speculation, just as are the scriptures that pro-life advocates use to oppose abortions. Neither group of scriptures should serve as a basis for laws either in favor of or against abortions and embryonic stem cell research.

At the end of the day, about all that one can objectively say about God's views about abortion and embryonic stem cell research is that the bible does not clearly state such views. But even if one could cite a biblical verse that unambiguously states God's opinion that abortions and embryonic stem cell research are immoral and against the Sixth Commandment, such would still not be a sufficient ground to support a law against abortion and embryonic stem cell research. As a matter of fact, any coercive law against abortion and embryonic stem cell research in the United States, even if the law is consistent with God's will, would be immoral to God because it would violate a more important doctrine that God apparently supports: the doctrine of free will.

As a full discussion of the religious doctrine of determinism/ predestination and free will is beyond the scope of this Article (given that these topics have occupied and confused scholars and philosophers for centuries),${ }^{101}$ this Article will briefly define the issue and review it through the lens of the Roman Catholic Church, the chief religious opponent of abortions and embryonic stem cell research. First, the age-old conflict between determinism and free will centers around whether God has predestined the actions and ultimate outcome of each human, or whether humans have the free will to choose their own actions and do either good or evil according to their own desires. ${ }^{102}$ Some scholars and theologians believe that the determinism doctrine expresses God's plan for us, while others believe that, contrary to God's having mapped out our lives, each person has the free will to plan and live his own life. ${ }^{103}$ This debate is important because if determinism is God's design for humans, then humans really cannot be responsible for their good

100. See id.

101. See David C. Williams \& Susan H. Williams, Volitionalism and Religious Liberty, 76 CorNELL L. Rev. 769, 859-61 (1991) (discussing different views regarding predestination and free will).

102. See id.

103. See id. 
and bad actions because God has predestined those actions and therefore humans have no control over them and should not be held morally responsible for their bad acts. ${ }^{104}$ In contrast, if free will is God's plan, then one should be held morally responsible for his or her bad acts. ${ }^{105}$ Most religious groups believe in free will. ${ }^{106}$ As the Roman Catholic Church is one of the most vocal opponents of abortions and embryonic stem cell research, a review of its views regarding determinism and free will is instructive.

That church has adopted the free will approach to human salvation. It believes that God does not force His salvation upon humans; rather, humans can freely choose whether they will do good or evil, and their volitional acts of good and evil will determine whether they go to heaven. As a matter of fact, the Roman Catholic Church has expressed its opinion in several of its catechism. Article 3, Man's Freedom, section 1730 of the catechism provides:

God created man a rational being, conferring on him the dignity of a person who can initiate and control his own actions. "God willed that man should be 'left in the hand of his own counsel,' so that he might of his own accord seek his Creator and freely attain his full and blessed perfection by cleaving to him." 107

\section{Section 1731 states:}

Freedom is the power, rooted in reason and will, to act or not to act, to do this or that, and so to perform deliberate actions on one's own responsibility. By free will one shapes one's own life. Human freedom is a force for growth and maturity in truth and goodness; it attains its perfection when directed toward God, our beatitude. ${ }^{108}$

And section 1732 asserts that:

As long as freedom has not bound itself definitively to its ultimate good which is God, there is the possibility of choosing between good and evil, and thus of growing in perfection or of failing and sinning. This freedom characterizes properly human acts. It is the basis of praise or blame, merit or reproach. ${ }^{109}$

104. See id. at 788 ("It, nonetheless, holds implications for the descriptive psychological or metaphysical issue of determinism and free will. Human beings must possess free will;6060;6060, in the sense of a power to the contrary, or no one could ever be liable under a volitionalist theory.").

105. See id. at 786

106. See id. at 788 ("Volitionalism, then, pervades our legal, religious, and intellectual culture. In fact, the volitionalist perspective is so common, so unquestioned, that it may be difficult even to imagine an alternative."); Richard Ruble,Determinism v.Free Will, http://www.asa3.org/ASA/PSCF/1976/JASA676Rubble.html ("Most Christians believe in some type of free will.").

107. Catechism of the Catholic Church 1730.

108. Id. at 1731 .

109. Id. at 1732 . 
Although the above-referenced sections from the catechism clearly show the Roman Catholic Church's support of free will doctrine, several other catechisms adds confusion to the Church's position on free will. Section 1740 provides, "The exercise of freedom does not imply a right to say or do everything. It is false to maintain that man, 'the subject of this freedom,' is 'an individual who is fully self-sufficient and whose finality is satisfaction of his own interests in the enjoyment of earthly goods." 110

The generality of section 1740 does not offer much guidance on the boundaries of the free will doctrine. But several catechisms on abortion offer some clarity. Section 2270 provides:

Human life must be respected and protected absolutely from the moment of conception. From the first moments of his existence, a human being must be recognized as having the right of a person - among which is the inviolate right of every innocent being to life. "Before I formed you in the womb I knew you and before you were born I consecrated you." (Jeremiah 1:5). ${ }^{111}$

And section 2773 states:

The inalienable right to life of every innocent person is a constitutive element of a civil society... . Their human rights depend neither on individuals nor on parents; nor do they represent a concession made by society and the state; they belong to human nature and protection must be ensured for the unborn child from the moment of conception. The law must provide appropriate penal sanctions for every deliberate violation of the child's rights (Gift of Life). ${ }^{12}$

Apparently, the Catholic Church would limit one free will when it comes to abortions. It seems that the church's opposition to abortion is in part based upon one of the biblical verses that are discussed above, Jeremiah $1: 5,{ }^{113}$ and upon the Sixth Commandment, ${ }^{114}$ which catechism 2258 explains as follows:

Human life is sacred because it is created by God and is meant for an everlasting relationship with God. God is the Lord of life (from beginning to end) and no one has

110. Id. at 1740 .

111. Id. at 2270 .

112. Id. at 2273 .

113. See supra note 57 and accompanying text.

114. See text accompanying supra notes 52-53. The Catholic Church refers to the Sixth Commandment as being the Fifth Commandment because of the version of the Ten Commandments that it has adopted. 
the right to destroy an innocent human being (Gift of Life-Congregation For the Doctrine of Faith). ${ }^{115}$

In light of the above-referenced catechisms on abortion and on the Sixth Commandment, it seems that the Roman Catholic Church would at least draw the outer boundaries of the free will doctrine to proscribe abortions. For example, Pope John Paul II, in a July 23, 2001, statement to President Bush states:

A free and virtuous society, which America aspires to be, must reject practices that devalue and violate human life at any state from conception until natural death. In defending the right to life, in law and through a vibrant culture of life, America can show the world the path to a truly humane future, in which man remains the master, not the product, of his technology. ${ }^{116}$

However, there is no real reason or justification that supports limiting the free will doctrine to deny one the free will to choose an abortion. Even if one were to accept that Jeremiah 1:5 and the Sixth Commandment establish that an embryo at the moment of conception has a soul and is just as morally valuable as a post-birth human, one should not use these biblical statements to limit the free will doctrine. At best these biblical sources would only establish that it would be immoral in God's eyes to kill an embryo through either an abortion or embryonic stem cell research. In other words, it would be a bad or an evil act to kill the embryo. But recognizing one's right to commit bad and evil acts is the essence of the free will doctrine. That is, unless God wants to force His salvation upon humans, humans must have the free will to choose evil acts. Because there is no evidence that God forces either morality or salvation upon humans, given that the world is full of "evildoers," the only logical conclusion is that God has allowed humans to guide themselves according to their own free will. God has not required anyone to love Him or to do good deeds so that he or she will go to heaven. Therefore, even if abortions and embryonic stem cell research are immoral in God's eyes, He has given humans the free choice to do these things. Therefore, the Roman Catholic Church, President Bush and others who would ban or limit abortions and embryonic stem cell research would deny the free will options of those who desire abortions and embryonic stem cell research. The opponents of abortions and embryonic stem cell research are seeking to do for God that which He has chosen not to do for Himself. They are trying

115. Catechism of the Catholic Church 2258.

116. Master, Not Product of Technology, supra note 7. 
to force humans to be good when God allows humans to make their own decisions about doing good or bad acts. ${ }^{117}$

This Author does recognize that there should be some limits to the free will doctrine. For example, many different countries proscribe and punish murder and other illegal acts. Given that some of these countries, including America, have created laws that recognize the separation of church and state, it is not logical to believe that one of the major reasons that murder and many other acts are illegal is that they pose a danger to the public safety and welfare and not necessarily because such proscribed conduct is immoral in God's view. Given such danger, despite any religious notions of free will, a government must protect its citizens and should proscribe bad acts that would kill or otherwise harm post-birth humans who have just as much of a right to happiness, liberty, and life as does one who wants to exercise his free will to commit illegal acts.

However, abortions and embryonic stem cell research do not fall into the same category of illegal acts that pose a danger to the public safety and welfare. The only entity that is harmed is the fetus or embryo, which the current federal law of this country does not recognize as being entitled to the same protection as post-birth humans. For the most part, abortions and embryonic stem cell research are victimless acts that one can deem immoral and against God's will only if one's religious viewpoint construes the bible as proscribing the destruction of embryos and fetuses. But forcing one's religious viewpoints upon another in such a way that it denies the other's free will to choose these practices appears to be just as immoral in God's eyes as are the proscribed acts. To some extent, such forcing of one's religious viewpoint upon another denies God the opportunity to see whether an individual faced with the choice of an abortion or with the need for medical treatment using embryonic stem cell research will choose the moral course of action, to have or not have these treatments according to that person's perception of God's views on such issues.

To the extent that some might argue that abortions and embryonic stem cell research are not victimless crimes because such practices deny a potential human being the opportunity after conception to develop and become a postbirth human, such an argument would place this country on a slippery slope that would lead to a further argument that the use of contraceptive devices are immoral and not victimless because they prevent the conception of potential human beings and waste human sperm and eggs, which must be given the 
same moral status of an embryo or fetus because the sperm and egg are the foundational substances that cause conception. It would seem that a law banning contraception would be the next logical step if abortions and embryonic stem cell research are banned.

But given the presence of the First Amendment in America's legal framework, the enforcement of prohibitive religious viewpoints on abortions and embryonic stem cell research, through the enactment of laws preventing such practices and the federal funding of such practices, would be in violation of the Establishment Clause.

\section{Violation of the Establishment Clause}

A central position of this Article is that a strong case can be made that President Bush's ban on embryonic stem cell research violates the Establishment Clause, as will be explained below. A brief discussion of the Court's Establishment Clause jurisprudence on the religious purpose prong of the Lemon test is instructive. ${ }^{118}$

\section{A. Political Debate in a Pluralist Democracy}

Some believe that religious viewpoints should be a part of the public debate on important governmental issues, while others believes that they should not. This Author believes that religious organizations and religious people should have access to public forums to express their views and influence their political leaders. ${ }^{119}$ In a pluralist democratic country, such as

118. See Lemon v. Kurtzman, 403 U.S. 602 (1971).

119. Some scholars advocate that, when considering the purpose behind a particular law, the Court should be very deferential and that the secular purpose requirement is typically met as long as there is some secular purpose, even if religious motivation was a substantial or even dominant influence behind the action. Mark W. Cordes, Politics, Religion, and The First Amendment, 50 Depaul L. Rev. 111, 170 (2000). Others believe that a law that is motivated by religious "morality that serves a secular function" is not violative of the religion clause, while a law that "simply condemns the activity because it is immoral" is unconstitutional. Arnold H. Loewy, Morals Legislation and the Establishment Clause, 55 ALA. L. REv. 159, 161 (2003). This author states:

The major issue is how to separate a legitimate state command from a state-enforced religious obligation. My answer is to first look to see whether the state commands adherence to a religious precept. If it does, I ask whether the state has a purpose beyond religious conformity. To measure that, I ask whether a substantial number of religious skeptics would support the proposal. If they would, the legislation is constitutional. If they would not, the legislation should be invalidated. Id. at 182 .

Scholars who hold these opinions are in the school of thought that religious viewpoints should be a 
America, it is desirable that persons with different viewpoints be allowed to express their ideas regarding public issues. ${ }^{120}$ A multiplicity of ideas frequently ensures that public officials consider different viewpoints that might lead to better decisions that maximize the broadest range of societal goods. There are several reasons why it is not prudent to advocate a limitation on participation by religious organizations in public debates. First, given the long history of such participation, there is no reason to believe that either the Supreme Court or Congress has the stomach to severely limit that participation. The only limitation on the participation of such organizations occurs when the Court strikes down laws that are impermissibly motivated by religious purposes. ${ }^{121}$ A second reason why the path of religious organizations to public debate should not be made too rocky is that some of these groups are so dogmatic that they might engage in violent retaliatory actions. ${ }^{122}$ Such

part of the public debate and that sometimes religious viewpoints can be a motivating force behind the enactment of laws and governmental actions as long as the religious purpose is not the exclusive motivation for the law. Professor Loewy opines that a religious purpose should not run afoul of the First Amendment as long as there is a "substantial number of religious skeptics" who would also support the law, apparently because these skeptics have a secular purpose for supporting the law. See id. He also states that "[t]he point is that religion can be a part of the public debate, but it has no privileged position. Indeed, so long as nobody is punished for failing to toe the religious line, I suggest that the community can enact legislation at the behest of a religious group." Id. at 176.

Professor Cordes would find no violation of the First Amendment even when a religious motivation is the predominate motivation for the law as long as the religious motivation is not the sole motivation for the law. Cordes, supra note 119, at 170.

On the other hand, other scholars believes that less deference should be given to religious speech and that there should be a strict separation between church and state such "that religion and government should remain separate, not only formalistically but also realistically" and that. "[r]eligion should be kept apart from the apparatus of the government, even though that goal will entail limiting private religious speech in circumstances where secular speech is permitted." Steven G. Gey, When Is Religious Speech Not "Free Speech"?, 2000 U. ILl. L. Rev. 379, 458 (2000). Scholars in this school fear that if religion plays too large a part in the resolution of public policy issues, "religious organizations [will] use the government as a tool for extending their influence over those who do not share their theology," and that such a domination will be detrimental to "the creation of a viable constitutional democracy." Id. at 460.

120. Martha Minow, Choice or Commonality: Welfare and Schooling After the End of Welfare As We Knew It, 49 DuKE L.J. 493, 558 (1999) (asserting that "these are fair questions that I hope will be aired and addressed if religious groups and others participate in a broad public debate about how to arrange for social provision in a pluralist society committed to tolerance, liberty, and equality").

121. As will be argued later, this Author believes that, when reviewing such impermissible laws, the Court should add teeth to its analysis under the secular purpose prong of the Lemon test. See infra notes 146 through 199.

122. Julia L. Ernst, Laura Katzive \& Erica Smock, The Global Pattern of U.S. Initiatives Curtailing Women's Reproductive Rights: A Perspective on the Increasingly Anti-Choice Mosaic, 6 U. PA. J. Const. L. 752, $778 \mathrm{n} .127$ (2004) (asserting that "[d] uring the relative lull in Washington, D.C., the far right largely took its battle to the state legislatures, as well as to the local communities, holding vigils outside abortion clinics, blocking clinic entrances, and resorting to violent tactics such as bombs, arson, and murder by the 
violent acts as the bombing of abortion clinics and the killing of physicians who perform abortions have not been beyond the pale for some who are adamant in their religious opposition to abortions. ${ }^{123}$ Even if violence will not occur, and it probably will not because most religious organizations and people are not violent, it is reasonable to believe that influential churches and other religious organizations will vigorously challenge any efforts to silence them during public debate. The mere possibility of substantial opposition from religious groups is enough to guarantee that there will be no future efforts to curtail the political activities of such groups. It is reasonable to believe that neither of the major political parties in this country has the stomach to suffer the loss of votes that surely would come as protest against any real efforts to curtail the free speech rights of religious organizations. ${ }^{124}$

A third and final reason is that religious organizations should have the same free access to political arenas as do secular organizations. The members of religious organizations pay taxes and make the same types of important contributions to this country that nonbelievers make, ${ }^{125}$ and they should have the same free access to politicians and other public policy makers as they attempt to influence the types of laws that our government adopts. This conclusion holds even when such organizations are acting purely for a constitutionally impermissible purpose of promoting their religious viewpoints and doctrines through legislative enactments.

But churches and other religious organizations must adhere to the separation of church and state as provided for in the First Amendment. Such organizations should not expect that the rest of society (which also has a voice and a right to petition its public officials for desired public policy outcomes) will freely submit to domination by religious groups. Nor should religious

more militant members")

123. See id. The violent propensities of such persons is readily shown by the fact that Justice Harry Blackmun, the author of the Court's Roe v. Wade opinion establishing that a woman has a constitutional right to an abortion, received many death threats and other harassment from those who opposed abortion, which apparently restricted his activities and general freedom. Morton J. Horwitz, Book Review, Changed by the Court: The Evolving Jurisprudence of Justice Blackmun and the Supreme Court, HARVARD MAG., http://www.harvardmagazine.com/on-line/070579.html (asserting that "[f]or most of his remaining two decades on the Court, [Justice Blackmun] endured a regular stream of abusive letters and hostile demonstrations, as well as a number of death threats including a gun shot that shattered a window of his apartment which restricted his movements and cast a melancholy pall over his existence").

124. Instead, to assist themselves in winning elections, both parties actively court churches and religious organizations, as reflected in part by Democrats beating a path to African-American churches during election campaigns and Republicans doing the same mostly to their religious right-wing base.

125. It would seem that the old adage "no taxation without representation" is applicable to religious organizations, except when their desired goals are in violation of the First Amendment. 
organizations believe that courts will assist them in efforts to force their religious doctrines upon nonbelievers. Instead, courts should redouble their efforts to ensure the constitutionality of public laws, especially in a time when the country is so evenly divided between Republicans and Democrats, some of whom (to obtain more votes in the next election) are eager to grant the wishes of religious organizations.

This Article take the position that, when faced with a challenge that a law violates the Establishment Clause, courts should engage in a more rigorous examination of the secular purpose for such law and be more willing to invalidate the law when its proponents cannot show that the legislative body would have enacted the law even if there had not been a religious purpose for the law. This more rigorous analysis can be obtained if the Court and lowerlevel courts change the burdens of proof for resolving Establishment Clause issues, as discussed below. ${ }^{126}$ But, before explaining these burdens of proof, a discussion of some current standards that the Court uses when analyzing these issues may be helpful.

\section{B. The Secular Purpose Doctrine}

In Lemon v. Kurtzman, ${ }^{127}$ the Court announced the three-part test for determining whether a law impermissibly intrudes upon the Establishment Clause: (1) "the statute must have a secular legislative purpose; (2) its principal or primary effect must be one that neither advances nor inhibits religion"; (3) "the statute must not foster "an excessive government entanglement with religion." "128 Without questioning the wisdom of this test, suffice to say that the Court has grappled with its application to specific fact patterns. It appears that the Court gives more deference to a law, and is not likely to find an Establishment Clause violation, when the law is a general police power regulation that provides public services through both secular and sectarian institutions. In such cases, the Court is less likely to reject a proffered secular purpose. For lack of a better name, this Article will label

126. See text accompanying infra notes 186 through 199.

127. Lemon v. Kurtzman, 403 U.S. 602 (1971).

128. Id. There has been much criticism over the propriety of the Lemon test and whether it is appropriate for Establishment Clause analysis. See Lisa M. Kahle, Making "Lemon-aid" from the Supreme Court's Lemon: Why Current Establishment Clause Jurisprudence Should Be Replaced By A Modified Coercion Test, 42 San Diego L. Rev. 349, 352-63 (2005) (discussing arguments for and against the use of the Lemon test). See also Gregory C. Sisk \& Michael Heise, Judges and Ideology: Public and Academic Debates About Statistical Measures, 99 Nw. U. L. Rev. 743, 759 n.103 (2005) (discussing views of some scholars regarding the ambiguity that the Lemon test has created). 
these types of governmental regulations as Level I Activities. The Court's decision in Lemon is representative of the type of Establishment Clause analysis that the Court will employ when reviewing such activities.

In Lemon, the Court held that state laws providing for reimbursements to nonpublic schools, including parochial schools, for textbooks, teachers' salaries, and other expenses when such nonpublic schools taught "secular subjects" was supported by a secular purpose because the laws stated that they were "intended to enhance the quality of the secular education in all schools covered by the compulsory attendance laws." ${ }^{\prime 29}$ Deferentially accepting the asserted secular purpose, the Court held that the laws did not violate the Establishment Clause. ${ }^{130}$

Similarly, the Court has liberally accepted secular purpose explanations for various laws while finding no constitutional violation, including state laws granting vouchers to students who attend religious schools, ${ }^{131}$ sending public school teachers into parochial schools to teach secular classes, ${ }^{132}$ funding a college newspaper with a Christian viewpoint, ${ }^{133}$ furnishing interpreters to deaf students who attended Catholic school, ${ }^{134}$ providing for grants to religious and other organizations so that they can provide teenage sexuality counseling, ${ }^{135}$ providing financial vocational assistance to a blind student who

129. Lemon, 403 U.S. at 613.

130. Id. In recognition of that deference, the Court made no attempt to go behind the statute's stated secular purpose to see whether it was the real purpose of the statute, or whether there was a religious purpose that also supported the state laws. See id. Rather, the Court simply assumed that the articulated purpose was the real purpose, stating "[a] State always has a legitimate concern for maintaining minimum standards in all schools it allows to operate." Id.

131. Zelman v. Simmons-Harris, 536 U.S. 639, 649 (2002) (asserting that "[t]here is no dispute that the program challenged here was enacted for the valid secular purpose of providing educational assistance to poor children in a demonstrably failing public school system").

132. Agostini v. Felton, 521 U.S. 203, 218-19 (1997) (relying upon prior precedent establishing that "[t]he Court acknowledged that the Shared Time program served a purely secular purpose, thereby satisfying the first part of the so-called Lemon test").

133. Rosenberger v. Rector \& Visitors of the Univ. of Va., 515 U.S. 819, 843-44 (1995) (“Any benefit to religion is incidental to the government's provision of secular services for secular purposes on a religion-neutral basis. Printing is a routine, secular, and recurring attribute of student life.").

134. Zobrest v. Catalina Foothills Sch. Dist., 509 U.S. 1, 5 (1993) (citing the lower court's conclusion that the law's secular purpose was "to assist States and Localities to provide for the education of all handicapped children").

135. Bowen v. Kendrick, 487 U.S. 589, 603 (1988) (“In adopting the AFLA, Congress expressly intended to expand the services already authorized by Title VI, to insure the increased participation of parents in education and support services, to increase the flexibility of the programs, and to spark the development of new, innovative services. .... These are all legitimate secular goals that are furthered by the AFLA's additions to Title VI, including the challenged provisions that refer to religious organizations. There simply is no evidence that Congress' 'actual purpose' in passing the AFLA was one of 'endorsing 
sought a Bible degree at a Christian college, ${ }^{136}$ applying the Fair Labor Standard Act to religious organizations, ${ }^{137}$ allowing a nativity scene as one part of a city's Christmas display, ${ }^{138}$ granting a tax deduction to parents who paid tuition and other expenses for their children to attend elementary and secondary schools even when such deductions would primarily benefit parochial schools, ${ }^{139}$ reimbursing parochial and other nonpublic schools for expenses incurred in giving tests mandated by state law, ${ }^{140}$ issuing bonds to assist colleges that did not have a significant sectarian orientation, ${ }^{141}$ granting

religion"').

136. Witters v. Wash. Dep't of Servs. for the Blind, 474 U.S. 481, 485-86 (1986) (asserting "[t]hat program [of assistance] was designed to promote the well-being of the visually handicapped through the provision of vocational rehabilitation services, and no more than a minuscule amount of the aid awarded under the program is likely to flow to religious education").

137. Tony \& Susan Alamo Found. v. Sec'y of Labor, 471 U.S. 290, 305 n.30 (1985) (stating that "[n]o one here contends that the Fair Labor Standards Act has anything other than secular purposes").

138. Lynch v. Donnelly, 465 U.S. 668, 681 (1984). The Lynch Court appears to establish that a religious purpose can be one purpose motivating governmental action as long as there is at least "a" secular purpose that also motivates the law:

The narrow question is whether there is a secular purpose for Pawtucket's display of the crèche.

The display is sponsored by the city to celebrate the Holiday and to depict the origins of that

Holiday. These are legitimate secular purposes. The District Court's inference, drawn from the

religious nature of the crèche, that the city has no secular purpose was, on this record, clearly erroneous. Id.

139. Mueller v. Allen, 463 U.S. 388, 395 (1983) (finding a secular purpose, the Court held that "Minnesota, like other states, could conclude that there is a strong public interest in assuring the continued financial health of private schools, both sectarian and nonsectarian. By educating a substantial number of students such schools relieve public schools of a correspondingly great burden - to the benefit of all taxpayers").

Similarly, in Sloan v. Lemon, 413 U.S. 825, 829-30 (1973), the Court found a secular purpose for a Pennsylvania law that reimbursed parents for the tuition expense incurred in sending their children to nonpublic schools:

[T] he Pennsylvania law is prefaced by "legislative findings," which emphasize its underlying secular purposes: parents who send their children to nonpublic schools reduce the total cost of public education; "inflation, plus sharply rising costs of education, now combine to place in jeopardy the ability of such parents fully to carry this burden"; if the State's 500,000 nonpublic school children were to transfer to the public schools, the annual operating costs to the State would be $\$ 400$ million, and the added capital costs would exceed $\$ 1$ billion; therefore, "parents who maintain students in nonpublic schools provide a vital service" and deserve at least partial reimbursement for alleviating an otherwise intolerable public burden. We certainly do not question now, any more than we did two Terms ago in Lemon v. Kurtzman, the reality and legitimacy of Pennsylvania's secular purposes.

Id. (footnotes omitted).

140. Comm. for Pub. Educ. \& Religious Liberty v. Regan, 444 U.S. 646, 654 (1980) (stating that "there is clearly a secular purpose behind the legislative enactment: '[T] o provide educational opportunity of a quality which will prepare [New York] citizens for the challenges of American life in the last decades of the twentieth century."” (quoting 1974 N.Y. Laws., ch. 507, § 1)).

141. Hunt v. McNair, 413 U.S. 734, 742 (1973) (accepting the secular purpose that was stated in the 
a property tax exemption to churches that are exclusively used to further their religious purposes, ${ }^{142}$ and providing that businesses shall close on Sunday. ${ }^{143}$

In the aforementioned situations, most involving a government's provision of secular services through both non-religious and religious organizations, the Court for the most part deferred to the secular purpose that the state articulated in support of general police power regulations of various activities, including education. These governmental regulations were chiefly for the purpose of providing certain functions that the government would have to provide if nonpublic and sectarian organizations did not provide them. In these areas of governmental regulations, the government's primary purpose is to help its citizens by eliciting, through various state funding arrangements, the help of such nonpublic institutions as private and parochial schools. The primary goal is to provide educational assistance and other secular services. ${ }^{144}$ Any secondary benefits to parochial schools, churches, and other religious organizations are purely incidental to the chief purpose of providing secular services. In such situations, it seems logical that courts should give deference to these governmental regulations as long as the articulated secular purposes underlying them are not shams. Therefore, it seems that the Court has struck a good balance when it frequently finds no violation of the Establishment Clause when opponents challenge a law in the Level I Activity category. ${ }^{145}$

language of the statute: "that it is the purpose of this chapter to provide a measure of assistance and an alternative method to enable institutions for higher education in the State to provide the facilities and structures which are sorely needed to accomplish the purposes of this chapter, all to the public benefit and good, to the extent and manner provided herein") (quoting S.C. CodE ANN. § 22.41 (Supp. 1971)).

142. Walz v. Tax Comm'n of New York, 397 U.S. 664, 687-89 (1970) (recognizing that a tax exemption law had a dual purpose of assisting religious organizations that provide many community services that the government would have to provide if religious organizations did not render such services and of recognizing that religious organizations increase pluralism and diversity by adding a different viewpoint to the public debate).

143. McGowan v. Maryland, 366 U.S. 420, 450 (1961) (“' [T]he State's purpose is not merely to provide a one-day-in-seven work stoppage. In addition to this, the State seeks to set one day apart from all others as a day of rest, repose, recreation and tranquility - a day which all members of the family and community have the opportunity to spend and enjoy together, a day on which there exists relative quiet and disassociation from the everyday intensity of commercial activities, a day on which people may visit friends and relatives who are not available during working days"). See also Two Guys From Harrison-Allentown, Inc. v. McGinley, 366 U.S. 582 (1961) (holding that Sunday closing law had a secular purpose).

144. See supra note 132 and accompanying text.

145. The inclusion of religious organizations within the class of citizens who benefit from state funding simply acknowledge the substantial role that religious organizations play in providing secular services to society in general. Governmental assistance, for Level I Activities, is a legitimate means of including religious organizations as partners with the government in providing secular services. It acknowledges that religious organizations, like people in general, are complex entities with a secular side and a sectarian side. There is no reasonable justification for preventing the government from using the 
However, different considerations are important when considering another area of governmental regulations. These regulations include sham efforts to pass laws or take other actions to aid or otherwise further religious organizations and their religious beliefs. These types of governmental actions fall within the Level II Activities category. Instead of using a deferential mode of analysis under the secular purpose prong of the Lemon test, the Court has frequently employed a more exacting interpretation when the facts show that a law singles out a religion or religious organization for special protection. Representative of this heightened scrutiny is the Court's decision in Board of Education v. Grumet, ${ }^{146}$ where the Court held that a New York state law that gave only one sect of Jews the right to establish its own school district (so that it could receive public funding of programs for disabled school children) was a violation of the Establishment Clause. ${ }^{147}$ Without rejecting the Lemon three-prong test, the Court was more concerned with whether the state law contravened certain broad principles that govern its Establishment Clause analysis. ${ }^{148}$ The Court in part held that, by creating a school district that exclusively benefited only one sect of Jews (and not other religious groups and nonsectarian groups) the law violated the neutrality principle that underlies the Establishment Clause. ${ }^{149}$ Principally, the Court held that the state law violated the Establishment Clause because it singled out a particular religious sect by providing it with a benefit (the granting of a school district status) that the state did not give to other villages, religions or groups. ${ }^{150}$

Mainly, the Court strictly construed the state law and refused to hypothesize a sufficient secular purpose to meet the first prong of the Lemon test. ${ }^{151}$ Applying strict scrutiny, Justice O'Connor, in her concurring opinion,

secular side of religious organizations to further secular purposes, especially when the government uses its individual citizens to further such secular purposes. Being more inclusive of religious organizations, when providing secular services, is more consonant with the higher ideals of full participation in a democratic society.

146. 512 U.S. 687 (1994).

147. See id. at $709-10$.

148. See id. at 703-10.

149. See id. The majority opinion did not specifically discuss whether the state law had a secular purpose. However, the Court recognized that principally the state might have been trying to give the religious sect a means of funding disability services to disabled children who otherwise attended the sect's parochial school. See id. at 691-95, 707-08.

150. See id. at 704-06.

151. It seems that one of the more important principles of law that stems from Grumet is that sometimes the Court will not confine itself to an analysis that always employs the Lemon test. Justice O'Connor's concurring opinion is even more telling; she asserted that there are different categories of cases that have been and that will be decided under the Establishment Clause. See id. at 718 (O'Connor, J, concurring in part and concurring in the judgment) (emphasis added) (quoting Larson v. Valente, 456 U.S. 
stated that " " $[\mathrm{t}]$ he clearest command of the Establishment Clause is that one religious denomination cannot be officially preferred over another. Just as we subject to the most exacting scrutiny laws that make classifications based on race . . s so too we strictly scrutinize governmental classifications based on religion." "152 Consistently, Justice Souter's majority opinion in Grumet opined that strict scrutiny was appropriate "for statutes singling out a particular religion for special privileges or burdens." 153

The Court's decision to give less deference to a law's alleged secular purpose when the law grants special benefits to religious organizations is also shown in Lee v. Weisman. ${ }^{154}$ Without using the Lemon test, the Court held that a "nonsectarian" prayer offered by a rabbi before and after a high school graduation was a state-sponsored support of religion in violation of the Establishment Clause. ${ }^{155}$ School officials provided guidelines controlling the content of the prayer. ${ }^{156}$ The Court's conclusion was premised in part on the fact that, in addition to being divisive, the school-sponsored prayer was coercive because it might pressure students to participate in the prayer when they did not want to, if for no other reason than to avoid pressure from peers and school officials. ${ }^{157}$ The Court gave no deference to the school official's contention that a secular purpose existed because a nonsectarian prayer was consistent with notions of "civic religion" and less offensive than a pure sectarian prayer. ${ }^{158}$

Some might limit Lee's holding to prayers in public schools where historically the Court has given less deference to alleged secular purposes for prayers because, in public schools, prayers tend to coerce students into accepting the intended religious messages. ${ }^{159}$ However, the Court in Lee made several statements that make it applicable to all cases where public governments adopt religious doctrines and impose them on citizens who would not freely submit to such doctrines if they had a real choice. The Court stated:

228, 249 (1982) and Employment Div. v. Smith, 494 U.S. 872, 886 n.3 (1990)). She indicated that different analytical tests might be used to analyze different categories of laws under the Establishment Clause. See id.

152. Id. at 714 .

153. Id. at 695 (majority opinion).

154. 505 U.S. 577 (1992).

155. See id. at $586-90$.

156. See id.

157. See id. at 588

158. Id. at 589 .

159. See id. at 592 . 
The First Amendment's Religion Clauses mean that religious beliefs and religious expression are too precious to be either proscribed or prescribed by the State. The design of the Constitution is that preservation and transmission of religious beliefs and worship is a responsibility and a choice committed to the private sphere, which itself is promised freedom to pursue that mission. It must not be forgotten then, that while concern must be given to define the protection granted to an objector or a dissenting nonbeliever, these same Clauses exist to protect religion from government interference. James Madison, the principal author of the Bill of Rights, did not rest his opposition to a religious establishment on the sole ground of its effect on the minority. A principal ground for his view was: "Experience witnesseth that ecclesiastical establishments, instead of maintaining the purity and efficacy of Religion, have had a contrary operation."160

\section{Similarly, the Court asserted:}

In religious debate or expression the government is not a prime participant, for the Framers deemed religious establishment antithetical to the freedom of all. The Free Exercise Clause embraces a freedom of conscience and worship that has close parallels in the speech provisions of the First Amendment, but the Establishment Clause is a specific prohibition on forms of state intervention in religious affairs with no precise counterpart in the speech provisions. The explanation lies in the lesson of history that was and is the inspiration for the Establishment Clause, the lesson that in the hands of government what might begin as a tolerant expression of religious views may end in a policy to indoctrinate and coerce. A state-created orthodoxy puts at grave risk that freedom of belief and conscience which are the sole assurance that religious faith is real, not imposed. ${ }^{161}$

To the extent that the First Amendment protects individual consciousness regarding religious beliefs, neither a state government nor the federal government should force religious beliefs upon their citizens. As will be argued below, this neutrality principal is applicable to the embryonic stem cell research debate, especially if President Bush's ban on federal funding of such research is an attempt to promote the belief of the Evangelical Right and the Roman Catholic Church that life begins at conception. ${ }^{162}$

In addition to Lee, other cases support a strict scrutiny of governmental actions that favor religious organizations and their doctrines. In County of Allegheny v. ACLU, ${ }^{163}$ the Court held that a city's display of a crèche in the

160. Id. at 590 .

161. Id. at 591-92 (citation omitted).

162. See infra notes 238-71. As such, the strict scrutiny and lack of deference that the Court applied in Lee is appropriate to an analysis of the constitutionality of the embryonic stem cell research funding ban. 163. 492 U.S. 573 (1989). The Court stated:

The "establishment of religion" clause of the First Amendment means at least this: Neither a state nor the Federal Government can set up a church. Neither can pass laws which aid one religion, aid all religions, or prefer one religion over another. Neither can force nor influence 
Grand Staircase of a public building during the Christmas season was a violation of the Establishment Clause. ${ }^{164}$ The Court applied the "endorsement test" that it had used in a previous case: "the government's use of religious symbolism is unconstitutional if it has the effect of endorsing religious beliefs, and the effect of the government's use of religious symbolism depends upon its context." ${ }^{165}$ The Court deemed the crèche to be an endorsement of religion because it contained a religious message "Glory to God because of the birth of Jesus" and because there were no other items in the display that obviated or distracted from the religious message. ${ }^{166}$

In addition to using the endorsement test, County of Allegheny referenced four principles that are relevant to the stem cell research debate. First, "The Establishment Clause, at the very least, prohibits government from appearing to take a position on questions of religious belief or from 'making adherence to a religion relevant in any way to a person's standing in the political community."" 167 Second, the "Court has come to understand the Establishment Clause to mean that government may not promote or affiliate itself with any religious doctrine or organization." 168 Third, “"[n]either a state nor the Federal Government can set up a church. Neither can [they] pass laws which aid one religion, aid all religions, or prefer one religion over another." "169 Fourth, "[n]o person can be punished for entertaining or professing religious beliefs or disbeliefs." referenced principles to hold that the crèche violated the Establishment Clause. ${ }^{171}$

a person to go to or remain away from church against his will or force him to profess a belief or disbelief in any religion. No person can be punished for entertaining or professing religious beliefs or disbeliefs, for church attendance or non-attendance. No tax in any amount, large or small, can be levied to support any religious activities or institutions, whatever they may be called, or whatever form they may adopt to teach or practice religion. Neither a state nor the Federal Government can, openly or secretly, participate in the affairs of any religious organizations or groups and vice versa.

Id. at 591 (quoting Everson v. Board of Education, 270 U.S. 1, 15-16 (1947)).

164. Id. at 601 .

165. Id. at 597 .

166. Id. at 598-99. Without using the Lemon test, the Court held that the mere fact that the crèche display conveyed a religious message in the context in which it was located, without anything to minimize that message, was enough to violate the Establishment Clause. Id. at 601-02.

167. Id. at 593-94 (emphasis added) (quoting Lynch v. Donnelly, 465 U.S. 668, 687 (1984) (O'Connor, J., concurring)).

168. $I d$. at 601-02 (emphasis added).

169. Id. at 591 (quoting Everson v. Bd. of Educ., 330 U.S. 1, 15-16 (1947)).

170. $I d$.

171. Id. at 601-02. Applying these principles to President Bush's ban on federal funding of 
Consistent with County of Allegheny, Lee, and Grumet are other opinions that strictly construe state laws that promote or otherwise benefit religious beliefs and hold that such laws are unconstitutional under the Establishment Clause, including state and local laws that grant tax exemptions status only for religious organizations, ${ }^{172}$ mandate the teaching of creation-science in public school to balance out the teaching of evolution-science, ${ }^{173}$ authorize a period of daily prayer and meditation, ${ }^{174}$ provide that a copy of the Ten Commandment be posted on public school walls ${ }^{175}$ and establish that the public school day starts with the reading of the bible. ${ }^{176}$

These court opinions are examples of when the Court will not give deference to a state's contentions that a secular purpose supports such laws that advance religion. Two overarching principles support the Court's

embryonic stem cell research leads to the conclusion that the ban violates the Establishment Clause because it is tantamount to the federal government's " $\operatorname{tak}[i n g]$ a position on [a] question[] of religious belief" that life and ensoulment begins at the point of conception and it is a promotion of and an affiliation with that religious doctrine. See infra notes 238-71 and accompanying text.

172. Texas Monthly, Inc. v. Bullock, 489 U.S. 1, 15 (1989) ("However, when government directs a subsidy exclusively to religious organizations that is not required by theFree Exercise Clause and that either burdens nonbeneficiaries markedly or cannot reasonably be seen as removing a significant state-imposed deterrent to the free exercise of religion, as Texas has done, ..., it 'provide[s] unjustifiable awards of assistance to religious organizations' and cannot but 'conve[y] a message of endorsement' to slighted members of the community.").

173. Edwards v. Aguillard, 482 U.S. 578, 586-87 (1987) ("While the Court is normally deferential to a State's articulation of a secular purpose, it is required that the statement of such purpose be sincere and not a sham").

The Court rejected the state articulated purpose of granting more academic freedom to teachers, because in requiring that teachers teach creation-science in addition to evolution-science, the state law actually limited teachers' freedom to teach what they wanted to teach if they did not think that it was desirable to teach creation-science. $I d$. at 587.

174. Wallace v. Jaffree, 472 U.S. 38 (1985) (holding that returning voluntary prayer to public schools was not a sufficient secular purpose; therefore, the law violated the Establishment Clause).

175. Stone v. Graham, 449 U.S. 39, 41-42 (1980). ("The pre-eminent purpose for posting the Ten Commandments on schoolroom walls is plainly religious in nature. The Ten Commandments are undeniably a sacred text in the Jewish and Christian faiths, and no legislative recitation of a supposed secular purpose can blind us to that fact. The Commandments do not confine themselves to arguably secular matters, such as honoring one's parents, killing or murder, adultery, stealing, false witness, and covetousness. . . Rather, the first part of the Commandments concerns the religious duties of believers: worshipping the Lord God alone, avoiding idolatry, not using the Lord's name in vain, and observing the Sabbath Day").

176. Sch. Dist. of Abington Twp. v. Schempp, 374 U.S. 203, 223-24 (1963) (rejected the alleged secular purposes of the statute, which were "the promotion of moral values, the contradiction to the materialistic trends of our times, the perpetuation of our institutions and the teaching of literature," and stating that "even if its purpose is not strictly religious, it is sought to be accomplished through readings, without comment, from the Bible. Surely the place of the Bible as an instrument of religion cannot be gainsaid"). 
reasoning. First, sometimes the Court will use strict scrutiny when considering whether a law impermissibly promotes or aids religion. ${ }^{177}$ Second, sometimes the Court will not even use the Lemon test when a state law runs afoul of the neutrality principle that underlies the Establishment Clause. ${ }^{178}$

When Level II Activities are compared to Level I Activities, one might conclude that the Court has struck a good balance in its Establishment Clause jurisprudence. For Level I Activities, the Court is more deferential, and appears more willing to accept a state's contention that an articulated purpose is a secular purpose. ${ }^{179}$ In many of the Level I cases, the issue involves the state providing money or some other support to its citizens through both sectarian and nonsectarian entities. ${ }^{180}$ The fact that sectarian organizations might garner incidental benefits that promote their religious purposes is not sufficient to cause an Establishment Clause violation if the primary purpose of the governmental action is one that the Court deferentially accepts as a secular purpose. ${ }^{181}$ The Court has reasoned that the Establishment Clause is not offended when a state enacts laws for secular purposes (such as supplying benefits to disabled students and reimbursements for mandatory testing of students) and allows the participation of both secular entities and sectarian entities in programs that further the mandate of such laws. ${ }^{182}$ The assistance of religious organizations in furnishing governmental services is desirable because frequently such organizations are just as equipped to provide these benefits as are non sectarian organizations, and their participation is consistent with the type of diversity in organizational involvement that some believe is desirable in a pluralist society. ${ }^{183}$ To some extent, the inclusion of religious organizations in Level I Activities might also make them more committed to democracy and more willing to submit to the rule of law. ${ }^{184}$

On the other hand, because Level II Activities involve attempts by the state to impose religion and religious doctrines upon people who might not

177. See supra text accompanying notes $152-54$.

178. See supra text accompanying notes $147-51$.

179. See supra text accompanying notes $130-46$.

180. See supra text accompanying notes $130-46$.

181. See supra text accompanying notes $130-46$.

182. See supra text accompanying notes $130-46$.

183. For a discussion of the parameters of legitimate involvement of religious organizations in political debate and the legislative outcomes of such debate, see generally Gey, supra note 119, at 379 . See also Michael W. McConnell, Believers as Equal Citizens, in Obligations of CitizenshiP And Demands of Faith: Religious Accommodation in Pluralist Democracies 90 (Nancy L. Rosenblum ed., 2000). 184. See supra text accompanying notes 126-27. 
want to submit to such theology, the Court should be increasingly more exacting in its review of such activities. ${ }^{185}$

\section{A Proposed Mixed Motive Test for Establishment Clause Analysis}

Not only is strict scrutiny and less deference appropriate for laws in the Level II Activities category, this Article takes the position that the Court's analysis should be even tougher. That is, the Court should abandon its current conclusion that there is no Establishment Clause violation when a state enacts a law for a religious purpose if there is also a secular purpose that supports the enactment of the law. ${ }^{186}$ Instead of allowing such mixed motive laws to escape a violation of the Establishment Clause, the Court should adopt a standard that is more in line with the type of mixed motive analysis that the Court employs when analyzing a Fourteenth Amendment challenge to laws that governments enact for a mixed racist and legitimate purpose. For example, in Hunter v. Underwood, ${ }^{187}$ the Court held that when a statute is motivated by a mixed motive, in that "racial discrimination is shown to have been a 'substantial' or 'motivating' factor behind enactment of the law, the burden shifts to the law's defenders to demonstrate that the law would have been enacted without this factor." 188 Applying the same principle to alleged Establishment Clause violations, courts should sustain mixed motive laws that governments in part enact for a religious purpose, only if the governments can

185. See supra text accompanying notes 147-79.

186. See supra note 139 and accompanying text.

187. 471 U.S. 222 (1985). In Hunter, the Court held that a racially neutral Alabama statute that disenfranchised those who were guilty of certain crimes involving moral turpitude was an unconstitutional violation of the Equal Protection Clause because one of the purposes underlying the law was the impermissible purpose of discriminating against African-American by denying them their right to vote. See id. at 233. The Court stated: "[W]e simply observe that [the disenfranchisement law's] original enactment was motivated by a desire to discriminate against blacks on account of race and the section continues to this day to have that effect. As such, it violates equal protection under Arlington Heights." Id.

188. Id. at 228 (citing Mt. Healthy City Sch. Dist. Bd. of Educ. v. Doyle, 429 U.S. 274, 287 (1977)). This mixed motive standard is analogous to the old mixed motive analysis that courts used for Title VII discrimination cases before Congress amended Title VII to provide for a new rule. In 1991, Congress amended Title VII to overrule the Court's decision in Price Waterhouse v. Hopkins, 490 U.S. 228 (1989), wherein the Court held that an employer who took an adverse action against an employee for both a legitimate purpose and for the impermissible discriminatory purpose could escape liability by showing that it would have taken the adverse action even if the impermissible purpose had not existed. See id. at 258. Under the 1991 amendment, the employer would be liable for certain equitable relief (injunctions and attorneys' fees but not compensatory damages) even if the discrimination was only one of the motivations for the adverse action and even if the employer shows that the action would have occurred without the impressible racial discrimination motive. 42 U.S.C. $§ 2000 \mathrm{e}-5(\mathrm{~g})(2)$ (B)(i) \& (ii) (2001). 
prove by a preponderance of the evidence that they would have enacted such laws even if there had been no religious motivation for the laws. ${ }^{189}$

If the Establishment Clause really gives one an entitlement to neutrality and to a consciousness of mind, as the Court has previously articulated as controlling principles ${ }^{190}$ the Court should ensure, to the fullest extent possible, that governmental authorities adhere to these principles when they enact laws and engage in other regulatory functions. To give maximum protection to the neutrality and consciousness of mind principles, the proposed mixed motive theory would create a default rule in favor of the invalidation of all laws that governmental entities would not have enacted had the asserted secular purpose been the only purpose that the entities considered before enacting the law. Such a default rule is important because normally there are many different motivations that support the enactment of laws and because the debate surrounding the enactment of most laws is so political that one cannot ascertain the true reason why the government enacted the laws. ${ }^{191}$

The Court, and lower-level courts, might shy away from employing the same type of mixed motive standard, as used in Equal Protection analysis, to Establishment Clause cases. However, there is no real reason why the analysis should be more lenient in Establishment Clause cases. Under the

189. In other words, the proponents of such mixed motive laws must establish, through sufficient statutory language, legislative history, or testimony from the proponents that the relevant governmental entity would have enacted the laws even if a religious purpose had not existed.

190. See supra text accompanying notes 147-50, 161-62.

191. Frequently, the real motivation supporting the enactment of a law is difficult to ascertain, especially on the national level, because the political debate surrounding the law is so contentious and nuanced that even well-educated people cannot decipher the real purposes underlying legislative enactments. See generally Bernard W. Bell, R-E-S-P-E-C-T: Respecting Legislative Judgments In Interpretive Theory, 78 N.C. L. REv. 1253, 1258 (2000) (alluding to textualists' disbeliefs regarding legislative history and their "assessment of the defects of the legislative process - the production of unnecessarily vague statutes, the drafting of misleading legislative history, and the dominant role of congressional staff and interest groups ....").

If the Establishment Clause really means that a government cannot force its chosen religions beliefs and doctrines upon its citizens, then the Court should willingly adopt the mixed motive default rule that this Article proposes, such that any errors that the Court might make in ascertaining the real purposes of laws during an analysis under the Establishment Clause should be in favor of striking down the laws that are not based solely upon a secular purpose. This is true because when a law is based upon both a secular purpose and a religious purpose courts frequently will not know which purpose was the predominate or real motivating force behind the enactment of the law. Clever legislators will manipulate words, phrases, and explanations to convince courts and the public that such laws have been enacted for a secular purpose, when in fact a religious purpose was the real motivation for the laws. Therefore, the proponents of challenged laws should have the burden of establishing that the laws would have been enacted even if there were no religious purposes for them. If they cannot do so by a preponderance of the evidence, then by default courts should hold that such laws violate the Establishment Clause. 
proposed mixed motive standard for Establishment Clause cases, the Court's analysis would be the same as for Equal Protection cases, with the only real difference being that an impermissible religious purpose would be the focus of the inquiry instead of an impermissible racial purpose. ${ }^{192}$ Any rejection by the Court of this mixed motive analysis might be because the Court believes that a default rule should favor religious people and religious organizations in close cases. Arguably, the current rule that a state can enact a law for a religious purpose if it also has a secular purpose in mind is a default rule where religious principles can influence the substantive outcomes of legislative enactments in close cases. One might even say that such victories by religious organizations in close cases are good because they promote the free exercise of religion and the full participation by all groups in obtaining desired legislative outcomes.

However, if the Establishment Clause is to have real meaning, religious people and religious organizations do not have a right to win legislative outcomes that promote their religious doctrines and agendas. Their own federal Constitution has denied them that right. Their remedy would be an amendment to that Constitution to change the First Amendment to a version that is more to their liking. ${ }^{193}$

192. However, in reading some of the Court's cases interpreting the Establishment Clause, it seems that the Court may be weary of using an interpretation that voids a law when a sectarian purpose is accompanied by a secular purpose. See infra note 235 and accompanying text. This is probably because the Court has difficulty determining how to reconcile notions of full participation by all citizens in lawmaking processes with the Establishment Clause's prohibition against the use of religious purposes to support laws and other governmental actions.

193. However, the Establishment Clause, according to the Court's current interpretation, does establish that governments cannot enact laws exclusively for a religious purpose. Lemon v. Kurtzman, 403 U.S. 602, 612-13 (1971). To further clarify the Establishment Clause requirement, the Court should impose a more exacting rule to resolve laws that are supported by mixed secular and sectarian purposes. Such might remove some of the uncertainty that legislators and other policy makers face when they enact laws. Presently, some legislators are in a bind because they are almost constantly bombarded with the arguments and positions that religious organizations take in favor of and against various public polices in such areas as abortion and stem cell research. However, the Establishment Clause seems to say that when these public officials cast votes in favor of or against proposed laws, they must forget about the positions and demands of religious organizations and vote in favor of or against the law only for a secular purpose. This quandary is exacerbated by the fact that political leaders will frequently have their own deep-seated religious views about the morality of a particular law. As such, it might be difficult for public officials to prevent sectarian motives from influencing their votes.

Therefore, pursuant to this Article's proposed mixed motive constitutional analysis for Establishment Clause challenges, the burden and degree of proof should be analogous to those in the Fourteenth Amendment context, but modified where necessary to take into consideration any differences that might exist in the religion clause context. As a general proposition, the proof offered to show a secular purpose should be more than just a sham. That is, in the Level II Activities context, there should be no deference 
Despite advocating a mixed motive constitutional analysis for the Establishment Clause, this Article does not take a pure separationist view that religious organizations and their supporters should be driven from the public square and that they should not have a voice in trying to convince public officials to pass laws that these organizations support. The proponent of a challenged law will win if he or she can show that the government would have enacted the law even if there had not been an impermissible religious motivation. The proponent will win even though religious purposes were a motivation for the enactment of the law. As such, religious organizations and the governmental officials who act on behalf of such organizations can both participate in political debates and win substantive outcomes if they satisfy the proposed mixed motive analysis. Such participation in and influencing of legislation seems to be more in accord with the full participation of all groups and individuals that makeup such a pluralist democracy as is America.

The mixed motive proposal in this Article is a good balance between the different interests that are involved in some of the Establishment Clause cases, especially cases involving the Level II Activities that the Article discusses above. The proposal recognizes that religious people and their organizations will engage in public debates. On the other hand, the proposal protects the right of nonadherents to be free from laws that promote and aid religious doctrines that such nonbelievers would rather not be governed by. Such protection is important because free consciousness of mind and governmental neutrality are important principles that underlie the Establishment Clause. These principles are paramount because, in our nuanced, manipulative society where frequently our politicians and other public officials do not always tell us the truth about their motives and purposes, a great deal of protection is needed to guard against the enactment of laws that will invariably be motivated by sectarian purposes. This conclusion is especially true given the growing presence of the religious right that continuously seeks to control the

given to a government's articulated secular purposes. The Court should look behind the asserted purposes, much as it did in the school prayer and moment of silence cases. See supra notes 155-59, 175 and accompanying text. If the challenger of a particular governmental regulation shows by a preponderance of the evidence that a religious purpose is one of the motivating purposes for the government's action, the burden should shift to the proponents of the regulation to show, by a preponderance of the evidence, that there is also a secular purpose that supports the regulation and that the government would have enacted the regulation even if there were no religious purposes underlying the statute. To the extent that it would be difficult for proponents of governmental action to win in mixed motive cases, such should be the price that the Establishment Clause imposes to guarantee to the fullest extent possible that governments and their religious supporters do not impermissibly force their theology and doctrines upon those members of society who do not ascribe to such beliefs. 
United States by promoting its religious agendas on abortion, embryonic stem cell research and a whole host of other issues.

Therefore, when one challenges a law under the Establishment Clause, a supporter of that law, to give full force and meaning to the Establishment Clause, should have a burden that requires her to persuade the Court and lower-level courts by a preponderance of the evidence that the government would have enacted the challenged law even if there were no religious purpose supporting the law. ${ }^{194}$

\section{Some Applications of the Proposed Mixed Motive Standard}

As the religious arguments against abortion are mostly the same religious arguments against stem cell research, the Court's treatment of an Establishment Clause argument against federal funding of abortion is instructive. In Harris v. McRae ${ }^{195}$ the Court held that the Hyde Amendment, which prohibits the use of federal funds for elective abortion, did not violate the Establishment Clause. ${ }^{196}$ Rejecting the assertion that the Amendment had a religious purpose because certain religious groups, such as the Roman Catholic Church, opposed abortion, ${ }^{197}$ the Court held that the Amendment "is as much a reflection of 'traditionalist' value towards abortion, as it is an embodiment of the views of any particular religion" and that "the fact that the funding restrictions in the Hyde Amendment may coincide with the religious tenets of the Roman Catholic Church does not, without more, contravene the Establishment Clause." 198 The phrase " "traditionalist' value towards abortion" is apparently a reference to an opposition that some had against abortions for many years before the Congressional debate on the Hyde Amendment. ${ }^{199}$ Because the Court adopted the district court's reasoning that the Amendment's enactment was a part of the traditional opposition against abortion that

194. It would not be efficient or logical to use the Establishment Clause to invalidate a law that a state would have enacted even if there were no impermissible purpose. The state could simply reenact the law without any consideration of the impermissible purpose, thereby avoiding an Establishment Clause violation. However, some might assert that such invalidation would serve as a deterrence against the future impermissible use of religion. Others might argue that the inefficiency of requiring the reenactment of laws, that would have been enacted even if there had been no religious purpose, outweigh any deterrent effect.

195. 448 U.S. 297 (1980).

196. Id. at 319-20.

197. See id.

198. Id.

199. Id. 
predated Roe v. Wade, ${ }^{200}$ a closer review of the district court's opinion is necessary.

The gist of the district court's opinion is that the challengers of the Hyde Amendment had not shown that the Amendment was initially enacted for a religious purpose. ${ }^{201}$ However, both the district court and the Supreme Court should have made a distinction between the purpose that existed at the time of the Amendment's enactment and the traditional opposition against abortion rationale that may have existed many years before the Congressional debate on the Amendment. For example, in Walz v. Tax Commission, ${ }^{202}$ the Court established that purposes can change from time to time and that, instead of the purpose that existed at the enactment of a law, the purpose that existed when one challenges a law is decisive for Establishment Clause purposes. ${ }^{203}$ The Court stated: "The only governmental purposes germane to the present inquiry, of course, are those that now exist." ${ }^{204}$ Unfortunately, the Court in Harris did not follow Walz, which if applied might have led to a different outcome. In other words, given the number of speeches by Congresspersons and Senators during the debate over the Hyde Amendment, the Court should have done a better job in explaining why the purpose of the Amendment was just as much a traditionalist opposition to abortion purpose as it was a religious purpose. Furthermore, the Court should have explained whether Congress would have adopted the Amendment had there been no religious purpose supporting it.

Instead of the district court glossing over the fact that "the most vigorous spokesmen for [the Hyde Amendments] put their case in religious terms, and grounded them in religious reasons," ${ }^{205}$ both the district court and the Supreme Court should have accepted Walz's conclusion that the decisive purposes are the ones that existed at the relevant point in time, which in that case was

200. Id. at 319 .

201. McRae v. Califano, 491 F. Supp. 630, 741 (E.D.N.Y. 1980).

202. 397 U.S. 664 (1970).

203. Id. at 687 n.8 (Brennan, J., concurring) ("The only governmental purposes germane to the present inquiry, of course, are those that now exist. As I said in Schempp, 'In the Sunday Law Cases, we found in state laws compelling a uniform day of rest from worldly labor no violation of the Establishment Clause ... . The basic ground of our decision was that, granted the Sunday Laws were first enacted for religious ends, they were continued in force for reasons wholly secular, namely, to provide a universal day of rest and ensure the health and tranquillity of the community. In other words, government may originally have decreed a Sunday day of rest for the impermissible purpose of supporting religion but abandoned that purpose and retained the laws for the permissible purpose of furthering overwhelmingly secular ends"). Id. (quoting Sch. Dist. v. Schmepp, 374 U.S. 203, 263-64 (1963)).

204. Id.

205. McRae, 491 F. Supp. at 741. 
during the enactment of the Hyde Amendment. The Court should have then held that the statute was motivated by a religious purpose if the religious arguments by Congresspersons and Senators were strong enough to establish a religious purpose. ${ }^{206}$ Both the district court and the Supreme Court should have asked whether the new religious arguments in support of the Hyde Amendment were sufficient to transform the old "traditional" opposition against abortion rationale into a new religious purpose for the Amendment. Just as a current racial motivation for governmental action can obviate the original purpose behind a legislative enactment, ${ }^{207}$ so should a current religious purpose for the enactment of, or continuation of, a law be sufficient to replace an earlier permissible motivation. ${ }^{208}$

Given the possibility that a new religious purpose can obviate the "traditionalist" purpose that allegedly supported the original opposition against abortion, the district court and the Supreme Court in Harris should have engaged in a more exacting evaluation of the extensive legislative history of the Hyde Amendment, as cited in the appendix of that opinion. ${ }^{209}$ That legislative history shows both the religious arguments and alleged secular arguments that proponents made during the debate over the enactment of the Amendment. First, Senator Helms' statements strongly shows that his vote in favor of the Amendment was based on his desire to protect religious people against having their tax dollars spent on abortions, which such persons believed were immoral:

To the argument that in a pluralistic society one group should not impose its beliefs on others, Senator Helms answered that he could think of no clearer imposition of one person's belief on another than "by requiring that person under penalty of law to finance activity to which he is morally, religiously, and philosophically opposed." He argued that the Senate had to consider whether it would force millions of Americans to violate

206. In other words, Walz seems to say that a subsequent religious purpose in support of a continued enforcement of a law or other course of action can obviate the original secular motivation for the law's enactment, thereby causing an Establishment Clause violation. See supra note 208.

207. Cf. Hunter v. Underwood, 471 U.S. 222, 233 (1985) (holding statute violates equal protection rights due to the discriminatory motivation when enacting the statute and the current discriminatory effects of enforcement of the statute).

208. In other words, just because there might have been a tradition against abortion that was not based upon a religious doctrine does not mean that the enactment of a current law, such as the Hyde Amendment, is pursuant to that preexisting tradition, especially when impermissible religious arguments are made during the Congressional debate surrounding the enactment of the law. See infra text accompanying notes 208-35.

Furthermore, the Court should have done a better job in explaining why the traditionalist opposition against abortion was not itself based upon religious doctrines.

209. McRae, 491 F. Supp. at 743. 
their long tradition of religious morality concerning abortion and force them to finance an act which they believed to be a homicide; he asserted that millions of Christians found in the Bible many indications that abortion is contrary to Christian morality. He quoted (ibid.) Jeremiah, Chapter 1, verse 5 (from the King James version):

"Before I formed thee in the belly I knew thee; and before thou camest forth out of the womb I sanctified thee..."

Senator Helms cited the June 1976 Southern Baptist Convention resolution as reaffirming the biblical sacredness and dignity of all human life, including fetal life, and stated:

"Practice of abortion for selfish non-therapeutic reasons wantonly destroys fetal life, dulls our society's moral sensitivity, and leads to a cheapening of all human life."

He argued that funding abortions restrained those who religiously opposed abortion in the free practice of their religion (ibid.). He admitted that a "legislative amendment" to an appropriation bill was generally undesirable, but urged (ibid.): "Even our most precious and longstanding constitutional principles admit of exceptions in certain circumstances. Today we are talking about the lives of hundreds of thousands of children about to be born and we are talking about a very positive and straightforward restraint on the freedom of religious practice by the use of the taxing power of the Federal Government. I believe that on balance, an exception and necessary on this occasion to our procedural practice." 210

Consistently, statements by Congressman Henry Hyde, the namesake of the Amendment, showed that his support of the Amendment might have been for a religious purpose because he continuously referred to his belief that human life starts at conception, and because he believed that the issues surrounding the Amendment "requir[ed] a determination whether or not 'the unborn person is human ...." 211 Such thinking that an embryo is a full human being at conception is commonly based upon one's religious beliefs; and therefore, it is significant that Congressman Hyde is a member of the Roman Catholic faith, ${ }^{212}$ one of the faiths that appears to be most adamantly against abortion in part because it believes that at conception an embryo is entitled to full moral recognition and legal protection. ${ }^{213}$

However, Congressman Hyde was shrewd enough to avoid a direct statement that a protection of religious beliefs is the motivation for his Amendment against the public funding of abortions. Instead, he tried to couch his statements that human life begins at conception in biological terms, asserting "that medicine, biology, embryology say that the growing living

210. Id. at 759 (quoting Senator Jesse Helms' statement) (emphasis added).

211. Id. at 744 (quoting Representative Henry Hyde's statement).

212. For a discussion of Representative Hyde's affiliation with the Roman Catholic Church, see John M. Swomley, The Vatican Connection: How the Roman Catholic Church Influences the Republican Party, Christian Ethics Today, Apr. 1997, available at http://www.christianethicstoday.com/Issue/010/ Issue_010_April_1997.htm.

213. See id. 
organism is a human life, that, once conception has occurred, 'a new and unique genetic package has been created, not a potential human being but a human being with potential . ...", 14

But, at other portions of the legislative history, Congressman Hyde arguably relies upon a religious purpose to support his Amendment: "The wholesale slaughter of the innocently inconvenient in this country could well be called a 'bloody business' and one that must make Herod's biblical slaughter of the innocents seem almost benign." 215

Other comments by members of Congress are relevant. A general statement by Congressman Paul arguably implies a similar religious motivation to protect religious people from having to financially support abortions; he stated: "This lack of concern for human life is an ominous sign of a decaying culture. We as a Congress must not contribute to this decay.... The use of tax dollars for abortion flaunts the first amendment protection of religious liberty.'" 216 This statement shows that Congressman Paul at least in part had a purpose of protecting religious persons' tax dollars from being spent on abortions because such persons might believe that such financial support of abortions is immoral and against a religious belief that life begins at the point of conception.

\section{Congressman Quie stated:}

Mr. Speaker, we are talking here about the right of people, because of their religious and moral belief, to not support taking the lives of human beings. . . When I first came to Congress, we could not even talk about birth control, which I believe in. We have come from birth control in 19 years all the way until now we are talking publicly about abortions in this country, and we could continue down the devil's toboggan slide to where we more and more accept as public policy, taking the lives of undesirable people after birth. Already this is occurring with some who are born deformed. ${ }^{217}$

Similarly, Congressman Paul stated: "Teenage abortion now is done with specific exclusion of parental consent, if the Government so chooses; another attack on religious convictions regarding the sanctity of the family."218 Congressman Russo asserted:

214. Harris, 491 F. Supp. at 744 (quoting Representative Henry Hyde's statement). Additionally, Congressman Hyde asserted: "that the fetus is not a diseased organ to be excised but a human being...." Id. at 752 .

215. Id. at 753 (quoting Representative Henry Hyde's statement) (emphasis added).

216. Id. at 753-54 (quoting Representative Paul's statement) (emphasis added).

217. Id. at 754-55 (quoting Representative Quie's statement).

218. Id. at 754 (quoting Representative Paul's statement) (emphasis added). 
"Millions of Americans of all religious persuasions and convictions have beseeched Congress to take firm action and halt the tragic and ever-increasing number of abortions performed in the United States every year."... He [Congressman Russo] acknowledged some merit in the argument that the amendment discriminated against poor women; he contended, however, that the argument was "overshadowed by the fact that every time a woman has an abortion, a human life is lost." 19

\section{Representative Badillo stated:}

Yes, there are people who, by their religious belief, feel that abortion is murder. Yet there were representatives of other religions who testified that life begins at birth, and still others stated that a child does not achieve the status of an individual until age of 1 year. Each group is convinced of the morality of their position, and within the ethical framework of their religion, each is correct. It seems to me, therefore, that it is absolutely untenable for this body to make the judgment that we will accept the morality of one segment of our society, and reject that of another. ${ }^{220}$

In accord is a statement by Senator Bob Packwood:

I cite[d] that list [of about fifty religious organizations that favored legalized abortion] to say that there is a religious division in this country as to whether or not we should have legalized abortion; a very significant portion of religious leadership in this country says yes, and a very significant portion says no. Under those circumstances, we should not, in this country, attempt to intervene on one side or the other in what is essentially a moral dispute. $^{221}$

Representative Badillo and Senator Packwood correctly believed that any decision to adopt the Amendment would be tantamount to an acceptance of some religious group's opinions over other religious groups' opinions regarding the morality of abortions. ${ }^{22}$ Senator Jesse Helms' statement provides support for that conclusion:

[T] he Senate had to consider whether it would force millions of Americans to violate their long tradition of religious morality concerning abortion and force them to finance an act which they believed to be a homicide; he asserted that millions of Christians found in the Bible many indications that abortion is contrary to Christian morality. He quoted ... Jeremiah, Chapter, 1, verse $5 .$.

219. Id. at 756 (quoting Representative Russo's statement).

220. Id. at 758 (quoting Representative Badillo's statement).

221. Id. at 760-61 (quoting Senator Packwood's statement). Senator Packwood's statement is consistent with the Court's opinion in County of Allegheny v. ACLU, 492 U.S. 573, 591 (1989) that the government violates the Establishment Clause when its promotes one set of religious doctrines or viewpoints over another set of such beliefs.

222. See supra notes 218-19 and accompanying text. 
"Before I formed thee in the belly I knew thee; and before thou camest forth out of the womb I sanctified thee... ."223

Additionally, Representative Guyer stated: "I think that we here should go on record as safeguarding that most precious commodity, the gift of little children from God, who have a right to live." ${ }^{224}$ Representative Stanton asserted:

[T] hat he had learned in the first grade not only the fundamental facts of his religion, but later on, to read the Constitution, and, he continued: "It seems to me there are certain unalienable rights that come from God and not from man, and among these is the right to life, liberty, and the pursuit of happiness according to the preamble to the Constitution." He asserted that "this is a question of a moral right." 225

It seems reasonably clear that the above-referenced statements from several Congressman and Senators during the debate over the Hyde Amendment show that some of the proponents of that Amendment supported its enactment because they wanted to protect and promote the beliefs of certain religious groups regarding the moral status of the fetus, a moral status that is grounded in religious doctrines regarding God and His intent about the moral value of a fetus' life. These statements should be enough to shift the burden of proof to the proponents of the Amendment to show by a preponderance of the evidence that Congress would have enacted the Amendment even if there were no religious purposes supporting the Amendment.

To meet that burden, the proponent might rely upon certain portions of the Amendment's legislative history to show a secular purpose for the Amendment. For example, Mr. Oberstar stated: “"[T] he right to life' was not primarily or exclusively a religious issue, that it was a human rights issue." ${ }^{226}$ Representative Hyde asserted:

223. McRae, 491 F. Supp. at 759 (quoting Senator Jesse Helms' statement) (emphasis added). Helms further cited the June 1976 Southern Baptist Convention resolution as reaffirming the "biblical sacredness and dignity of all human life, including fetal life...." Id. (quoting Senator Jesse Helms' statement). Helms concluded that: "Today we are talking about the lives of hundreds of thousands of children about to be born and we are talking about a very positive and straightforward restraint on the freedom of religious practice by the use of the taxing power of the Federal Government." Id. (quoting Senator Jesse Helms' statement).

224. Id. at 744 (quoting Representative Guyer's statement) (emphasis added).

225. Id. at 779-80 (quoting Representative Stanton's statement) (emphasis added).

226. Id. at 767 (quoting Representative Oberstar's statement). 
The old argument that we who oppose abortion are trying to impose our religious concepts on other people is totally absurd. Theology does not animate me; biology does. That is a human life; that is not a potential human life; it is a human life with potential.

When a pregnant woman, who should be the natural protector of her unborn child, becomes its deadly adversary, then it is the duty of this legislature to intervene on behalf of defenseless human life. ${ }^{227}$

\section{Representative Dornan asserted:}

[I]n eliminating federal funding for elective abortions, Congress was motivated by two legitimate concerns, to protect the potentiality of human life, and to avoid spending federal funds to support an activity many taxpayers felt to be morally repugnant; these concerns, he said, constitutionally justified the distinction Congress drew between abortion and childbirth. ${ }^{228}$

There are other portions of the legislative history of the Hyde Amendment that one might rely upon to support an argument that some of the Congresspersons who voted for the Amendment did so for a secular purpose. ${ }^{22}$ Whether the proponents of the Amendment can meet the preponderance of the evidence test that Congress would have enacted the Amendment even if there were no religious purposes underlying it, is a question for the trier of fact. ${ }^{230}$

In sum, given the substantial religious statements by Senator Helms and others during the debate on the Hyde Amendment, at the very least, the district court in McRae should have held that the challengers had presented enough evidence to shift the burden to the proponents of the Amendment, as there are substantial statements that show a religious purpose. Then, the proponent of the Amendment would have had a duty to produce other statements and evidence to show by a preponderance of the evidence that there was a secular purpose supporting the Amendment and that the government would have enacted the Amendment even if there were no religious purpose. ${ }^{231}$

227. Id. at 773 (quoting Representative Hyde's statement).

228. Id. at 774 (quoting Representative Dornan's statement).

229. See id. at 770-844 (discussing the legislative history of the Hyde Amendment, including statements from various members of Congress).

230. If the proponents cannot meet their burden, a court or other trier of fact should hold that the Amendment violates the Establishment Clause. When the evidence that is presented to show a religious purpose is balanced against the evidence that Congress would have enacted the Amendment even if there were no religious purposes is in equipose, the proponents of the Amendment should lose because they would not have shown that it is more likely than not that Congress would have enacted the Amendment without the religious purpose.

231. In addition to the statements quoted above where some of the Congresspersons asserted that religion was not a motivating factor in their support of the Amendment, a proponent might offer other 
legislative history statements to meet her burden. See McRae, 441 F. Supp. at 770-844.

Another example of when the mixed motive proposal that this Article offers might lead to a different conclusion regarding the constitutionality of a governmental enactment is Webster v. Reproductive Health Services, 492 U.S. 490 (1989). In Webster, the Court declined to pass on the constitutionality of the preamble of a Missouri statute that regulated certain aspect of abortion, although it did consider the constitutionality of other provisions. Id. at 506-07. The preamble provided that: "[t]he life of each human being begins at conception," and that "[u]nborn children have protectable interests in life, health, and wellbeing." Id. at 504 n.4. The contention of those who challenged the law was that the purpose of the preamble was to allow its definition of when life begins to control the interpretation of other provisions of the statute such that it might prohibit physicians in public medical facilities from giving certain types of contraceptives to their patients. Id. at 505-06. The state contended that the preamble did not impose any limitation on one's right to an abortion. Id. at 505. The Court declined to review the constitutionality of the preamble because there was no present attempt to apply the preamble to limit one's right to either contraceptive or an abortion. $I d$. at 506. In effect, the Court held that the challenge was hypothetical and should await the day when one attempts to apply the preamble to a concrete case involving contraceptive and abortions. Id. at 506-07.

However, Justice Stevens, in his concurring in part and dissenting in part, argued that the preamble violated the Establishment Clause of the First Amendment, even if it did not have a substantive implication on contraceptives and the right to an abortion. Id. at 566 (Stevens, J., concurring in part and dissenting in part). He reasoned that the preamble "rests on the fact that ... an unequivocal endorsement of a religious tenet of some but by no means all Christian faiths, serves no identifiable secular purpose" and "[t]hat fact alone compels a conclusion that the statute violates the Establishment Clause." Id. at 566-67. He called upon the state to offer a secular reason for its preamble, and specifically rejected any theory that the state had a secular purpose of wanting to promote childbirth as a means of increasing its population. Id. at 568-69. Similarly, he did not think that a secular purpose could legitimately be "based on a strict balancing of fiscal costs and benefits, [because] the economic costs of unlimited childbearing would outweigh those of abortion." Id. at 569. And, he rejected any secular purpose that the state might have had of " protecting a young pregnant woman from the consequences of an incorrect decision, "' given that such a purpose "does not justify the state legislature's official endorsement of the theological tenet embodied" in the statute's preamble. Id. at 569-70 (quoting Planned Parenthood of Central Mo. v. Danforth, 428 U.S. 52, 102 (1976) (Stevens, J., concurring in part and dissenting in part). Justice Stevens concluded:

Bolstering my conclusion that the preamble violates the First Amendment is the fact that the intensely divisive character of much of the national debate over the abortion issue reflects the deeply held religious convictions of many participants in the debate. The Missouri Legislature may not inject its endorsement of a particular religious tradition into this debate, for " $t \mathrm{t}] \mathrm{he}$ Establishment Clause does not allow public bodies to foment such disagreement."

Id. at 571 (footnote omitted) (quoting County of Allegheny v. ACLU, 492 U.S. 573, 651 (1989) (Stevens, $\mathrm{J}$., concurring in part and dissenting in part)).

An important part of Justice Stevens' opinion is his belief that the proponents of the Missouri statute should be required to show a secular purpose for the law to avoid an Establishment Clause violation. Id. at 568-69. However, Justice Stevens and the Court should reconsider at least one of his comments in light of the mixed motives standard that this Articles offers.

That comment is Justice Stevens' assertion that his conclusion that the preamble violated the Establishment Clause was not premised upon "the fact that the legislators who voted to enact it may have been motivated by religious consideration." Id. at 566 . He stated that his conclusion "rests on the fact that the preamble, an unequivocal endorsement of a religious tenet of some but by no means all Christian faiths, serves no identifiable secular purpose." Id. at 566-67 (footnote omitted). Therefore, it appears that if the preamble had a secular purpose, Justice Stevens would have upheld the law despite that the legislature was motivated by a religious purpose when it enacted the statute. However, the position that this Article takes 


\section{E. Applying the Mixed Motive Proposal to President Bush's Ban on Embryonic Stem Cell Research}

Several of the same religious arguments that some have asserted to influence the debate over abortion appear to be the motivation behind President Bush's ban against federal funding of embryonic stem cell research. ${ }^{232}$ These arguments are based upon the alleged full moral status of an embryo from conception. However, any belief in the sanctity of embryos from the date of conception is not a belief that is supported by existing secular law in America. Clearly, the Supreme Court in its right of privacy jurisprudence, from Roe v. Wade $e^{233}$ to Planned Parenthood of Southeastern Pennsylvania v. Casey, ${ }^{234}$ has not established that an embryo from the moment of conception is entitled to any protection that would outweigh a woman's unfettered right to destroy, through an abortion, the life of the embryo during the first two trimesters.

Roe's and Casey's affirmation of abortion should have led President Bush to authorize the federal funding of embryonic stem cell research. If one can abort in vitro embryos and fetuses for any reason (good or bad), and destroy excess embryos that are not needed for in vitro fertilization, there is no legal reason why one should not be able to destroy the same excess embryos to harvest stem cells that may be useful for medical treatment of post-birth

is that, even with a secular purpose for the law, the law was still in violation of the Establishment Clause unless the statute's proponents could show by a preponderance of the evidence that the government would have enacted the law even if there were no sectarian purpose supporting its enactment.

Therefore, in Webster, it would seem that one way of determining whether the preamble serves a secular purpose is to examine the motivation of those who enacted it to ascertain whether they acted pursuant to religious purposes. If the preamble was enacted for a religious purpose, then courts should not try to save it from being an Establishment Clause violation by hypothesizing a secular purpose for the preamble that was not within the contemplation of those that enacted the preamble. Instead, proponents of the challenged law should be required to show that the legislature would have enacted the law even if there had been no religious purpose. This same conclusion should apply to any governmental statute or regulation that one challenges under the Establishment Clause.

In sum, pursuant to the proposal in this Article, a mixed motive law violates the Establishment Clause unless the proponents can show that the government would have enacted the law even if there were no religious purposes underlying the law.

232. Stuart Brown, Superman and Stem Cell Research, Oct. 15, 2004, http://www.firstscience.com/ site/editor/074 ramblings 15102004.asp ("If you believe that conception is the point at which life begins then you will inevitably take issue with embryonic stem cell research because you may conclude that it is no different from abortion").

233. 410 U.S. 113 (1973).

234. 505 U.S. 833 (1992). 
humans who suffer from debilitating diseases. The only logical conclusion is that President Bush's August 2, 2001, ban on federal funding is based on his religious opposition to stem cell research; and therefore, his ban violates the Establishment Clause, which should proscribe any federal law or policy that is solely motivated by a sectarian or religious purpose. ${ }^{235}$ Certain statements from President Bush's speech announcing the August 9, 2001, ban show the violation:

I also believe human life is a sacred gift from our Creator. I worry about a culture that devalues life, and believe as your President I have an important obligation to foster and encourage respect for life in America and throughout the world. And while we're all hopeful about the potential of this research, no one can be certain that the science will live up to the hope it has generated. ${ }^{236}$

This statement is some evidence that President Bush believes that embryos are just as valuable as post-birth human. He believes that they are "a sacred gift from our Creator." ${ }^{237}$ This statement, in and of itself, is tantamount to a governmental acceptance of a religious belief in a Creator over an atheistic disbelief in a Creator. ${ }^{238}$

President Bush's August 9, 2001, statement further provides:

At its core, this issue forces us to confront fundamental questions about the beginnings of life and the ends of science. It lies at a difficult moral intersection, juxtaposing the need to protect life in all its phases with the prospect of saving and improving life in all its stages. ${ }^{239}$

This statement also shows the President's religious motivation because it refers to the age old debate between religion and science on the meaning of and the source of human life. Such a debate is one of the fundamental tensions that occupy many religious organizations. There is Supreme Court

235. Lemon v. Kurtzman, 403 U.S. 603, 612-13 (1970).

236. Bush, supra note 20.

237. See id. at 3.

238. One can make a good argument that a belief in a Creator is one of the most fundamental doctrines of most religious organizations. An opposing atheistic position is that there is no Creator. The Establishment Clause jurisprudence establish that governmental policies should neither be based upon nor further religious doctrine. Therefore, President Bush's acceptance of the idea that there is a Creator and his use of such a belief to ban the federal funding of embryonic stem cell research violate the Establishment Cause because the ban is a governmental selection of one set of religious beliefs over an opposing set of beliefs and because it promotes religious doctrine regarding the existence of a Creator. See County of Allegheny v. ACLU, 492 U.S. at 601-02 (1989) ("Court has come to understand the Establishment Clause to mean that government may not promote or affiliate itself with any religious doctrine or organization."). 239. Id. 
precedent that the government should not interject itself into such debates by choosing religious viewpoints or doctrines upon which to base governmental policies. ${ }^{240}$

To garner the full meaning of the President's August 9, 2001 statement, one should examine the President's commitment to religious principles and his past involvement with the promotion of religious doctrines. For example, during one of the Presidential debates while he was running for President, President Bush stated that Christ was his favorite philosopher. ${ }^{241}$ His religious motivation emanates from his Evangelical Christian ${ }^{242}$ faith which underlies his efforts to change the moral fiber of this country to bring it in line with his religious faith. ${ }^{243}$ President Bush's use of religion to support his political decisions has not gone unnoticed. Many non-Christians have criticized him for his frequent attempts to interject religious beliefs into public policy debates. ${ }^{244}$ Some have noted his statements that he was "chosen by the grace of God to lead" this country at the moment of the September 11 attack, and that, instead of going to his earthly father, "[t]here's a higher Father than that I appeal to," as evidence of his interjection of religion into public debate. ${ }^{245}$

That President Bush's ban on embryonic stem cell research is motivated by religion arguably is shown by his courting of and close ties to Roman

240. See id. at 593-94 ("The Establishment Clause, at the very least, prohibits government from appearing to take a position on questions of religious belief').

241. Jill Lawrence, Bush's Agenda Walks the Church-State Line, USA TodAY, Jan. 30, 2003, at 9A. Arguably, President Bush's statement about Jesus being his favorite philosopher was a part of his efforts to shore up his base of Christian supporters.

242. Johnathan Steinberg, A Mighty Fortress is His God; President Bush's Form of American Evangelicalism Enjoys Massive Popular Appeal and, Arguably, Influences Policy, The Miami Herald, July 18, 2004, available at http://www.informationclearinghouse.info/article6530.htm.

243. Id. This commentator states:

Exit polls in 2000 showed that 55 percent of those who voted for Bush placed moral reform as their highest political objective. All the so-called "hot-button issues" of this campaign — conflicts over gay marriage, abortion, guns, feminism or stem-cell research—reflect that. All those issues grow out of what evangelicals call "secular humanism"- a movement they believe has debauched American life in form of feminism, moral relativism, Bible criticism, Darwinian evolution and, worst of all, abortion.

Id.

244. John F. Dickerson \& Karen Tumulty, The Love Him, Hate Him President, Time, Dec. 1, 2003, at 28 (stating that Bush's support among those who do not attend church is low, and that $68 \%$ of Democrats and $32 \%$ of Republicans agree that "Bush has been too quick to interject his own moral and religious beliefs into politics").

245. Mary Ellen Schoonmaker, Dangerous Game: Mixing Religion, Politics, The Record (Bergen County, NJ), June 16, 2004, at L9. Some observers also rely upon Bush's many references to religion in his speeches as an attempt to gain religious voters for his reelection. See id. 
Catholic Church leaders, before and after his becoming President. ${ }^{246}$ For example, in a speech at the dedication of the Pope John Paul II Cultural Center in March of 2001, President Bush showed his support for religious doctrine by stating that: "We must defend in love the innocent child waiting to be born." ${ }^{247}$ Given the Roman Catholic Church leaders' adamant opposition to all forms of abortions, it is clear that the above-referenced statement, before Catholic church leaders, about protecting the unborn was an attempt by President Bush to show his acceptance of the Catholic church's religious doctrine that the fetus is a full human person that should be accorded the same moral value as post-birth humans. ${ }^{248}$ Arguably, the same religious doctrine

246. Bill Berkowitz, Bush's Campaign Courting Catholics, Aug. 7, 2001, http://www.alternet.org/ story/11291 ("Although going after the Catholic vote isn't a new phenomenon, the GOP has been devoting a lot of resources to this project, specifically focusing on religiously active Catholics. A bi-product of this effort has been the opening of another front in America's 'culture wars"'). President Bush efforts to gain the support of Catholic Church leaders have been somewhat successful because a conservative strand of the Catholic Church has become more involved in politics and has tried to gain the same type of political clout that certain evangelical groups have obtained. See id. Some of these conservative Catholic groups have gone so far as advocating the excommunication of Democrats who do not support the Catholic Church's position of abortion and similar issues. See id.

There is a long history of political lobbying by the Roman Catholic Church leaderships, in part through Catholic conferences in different states to oppose any federal funding of family planning methods that rely upon birth control through any means other than natural family planning. John M. Swomley, Political Power of Roman Catholic Bishops, The Human Quest, May-June 1992, at 14 (citing The Holy Alliance, Time, Feb. 24, 1992), available at http://www.population-security.org/swom-92-05.htm. These efforts including certain bishops testimony against the use of federal money to fund private agencies that promote non natural birth control; bishops' successful persuasion of the Carter Administration to withdraw the Food and Drug Administration's approval of Depo-Provera contraceptive, which is used in at least ninety other countries; bishops' successful persuasion of the Reagan Administration to ban federal funding of any international family planning agency that promote either abortion or artificial birth control; the U.S. Catholic Conferences lobbying of Congress to prevent the U.S. Agency for International Development (AID) from reinstating a requirement that internal international family planning agencies must give their clients informed consent disclosure about various different birth control methods; and the U.S. Catholic Conference 1986 effort to persuade Congress to stop federal funding of research on contraception while at the same time trying to include abstinence as method of family planning and make the AID the largest financial supporter of natural family planning. See id.

Additionally, the Catholic Church was instrumental in obtaining passage of the Adolescent Family Life Act which prevented the funding of groups that promoted abortions and which required that religious organizations, like the Catholic Church, be included among the organizations that receive funding for family planning. See id. The bishops were also successful in obtain research grants for Georgetown, a Catholic university, to study international family planning projects. See id.

247. Bush Boosts Pope's Ideal of "Culture of Life," Catholic World News, Mar. 23, 2001, https://cwnews.com/news/viewstory.cfm?recnum=15130.

248. In 2004, some bishops of the Roman Catholic Church, which is especially opposed to abortion and stem cell research, threatened to deny communion to politicians who do not oppose abortions and stem cell research. Bishop: Bar Communion for Abortion-Rights Voters, May 14, 2004, http:// forums.bigbigsavings.com/printthread.php3?t=402522 (quoting a Roman Catholic bishop statement that 
motivated President Bush's August 9, 2001, ban on the federal funding of future lines of embryonic stem cell research. ${ }^{249}$

There are other attempts by President Bush to show his support for Roman Catholic Church doctrines. For example, he has made appeals to the Pope and to the Vatican's Secretary of State, Cardinal Angelo Sodano, for the Pope's help in urging Catholic Bishops in America to more aggressively advocate against abortion and stem cell research. ${ }^{250}$ Additionally, in one

"[a]ny Catholic politicians who advocate for abortion, for illicit stem cell research or for any form of euthanasia ipso facto place themselves outside full communion with the church and so jeopardize their salvation . . . ."); Pulpit Politics: Israel Kerry's The Day, The Hotline, Aug. 5, 2004, available at http://nationaljournal.com/cgi-bin/ifetch4?ENG+HOTLINE+7-hot0195+1164495. These Catholic leaders believe that "Catholics in political life have the responsibility to exemplify in their public service the teaching of the church." See id. Such thinking calls into question whether any public policy that is based upon Catholic public officials' religious beliefs is a violation of the Establishment Clause, as will be more fully discussed below.

Although other religious groups vote for or against political candidates based upon religious beliefs, it appears that some evangelicals and some Roman Catholic leaders more adamantly interject their religious views into public debate as they try to influence political candidates and public officials. See $i d$. (discussing Jewish and Muslim support for Presidential Candidate John K. Kerry). Religion is playing a larger part in political debates because many political controversies involve moral debates, including such controversy as same-sex marriage and stem cell research. See id. (asserting that the GOP is "increasingly composed of religious traditionalists and centrists," while Dems consist of "religious liberals, devout secularists, and the religiously indifferent" and that " $[\mathrm{t}] \mathrm{here}$ is a God gap and the Democrats are recognizing it ....") (citations omitted).

The political influence of the Roman Catholic Church is problematic especially given that a substantial majority of its members support both abortion and stem cell research, which may indicate that the Catholic Church leadership is out of touch with its flock. Edd Doerr, The Man Behind the Curtain-Pope John Paul II, The HumAnist, July 1, 1999 (asserting that "[o]ver at least the last forty years, opinion polls have clearly shown that varying majorities of U.S. Catholics, as well as those in other developed countries, have come to disagree with their church leadership on such issues as divorce, remarriage after divorce, contraception, abortion, clerical celibacy, ordination of women, the importance of parochial education, and democracy within the church").

249. Additionally, Bush's August 9, 2001 ban may have been influenced by the pressure that certain religion groups applied against him. Terry Schlossberg, PPL Responds to President Bush's Decision on Federal Funding for Stem Cell Research, Aug. 15, 2001, http://www.ppl.org/TS_StemCell_ResponseAug01.html (asserting that the United Methodist, the Roman Catholic, and the Southern Baptist Convention oppose stem cell research (apparently on the ground that the embryo is a human life) and show a "strong opposition to [President Bush's] decision to permit federal funding of research on stem cell lines derived from embryos which have already been destroyed for research purposes in private laboratories"). The ban, which allowed federal funding of existing lines of embryonic stem cells but banned such funding for future lines, might have been a compromise that President Bush believed would please his religious right base of supporter. Id.

250. John L. Allen, Jr, Identity Politics in Switzerland; The Vatican and America: Personnel Changes in the Holy See; Bonhoeffer and Ratzinger, National Catholic Reporter, June 11, 2004, available at $\mathrm{http} / / \mathrm{www}$.nationalcatholicreporter.org/word/pfw061104.htm. This commentator states:

A Vatican official told NCR June 9 that in his meeting with Cardinal Angelo Sodano and

other Vatican officials, Bush said, "Not all the American bishops are with me" on the cultural 
meeting at the Roman Catholic Knights of Columbus Convention in August 2004, President Bush asserted that "he considered them vital allies in his efforts to support religious charities, defend traditional marriage, and promote a 'culture of life' in America." 251 The President stated "I believe government needs to stand on the side of faith-based groups, not against faith-based groups." ${ }^{252}$ At a minimum, the President's courting of the Roman Catholic Church leaders and voters, as well as evangelical voters, calls into question his motivation for the August 9, 2001, ban on embryonic stem cell research and on other issues where he has taken positions that further the religious doctrines of the Roman Catholic Church and that of his evangelical supporters. ${ }^{253}$

issues. The implication was that he hoped the Vatican would nudge them toward more explicit activism.

Other sources in the meeting said that while they could not recall the president's exact words, he did pledge aggressive efforts on the cultural front, especially the battle against gay marriage, and asked for the Vatican's help in encouraging the U.S. bishops to be more outspoken.

According to sources, Sodano did not respond to the request.

Sources say Bush made the remark after Sodano thanked him for his stand on the issues of family and life. They also said that while Bush was focusing primarily on the marriage question, he also had in mind other concerns such as abortion and stem cell research. Id. 251. Ron Hutcheson, Bush Says He Is Catholics' Ally Before the Knights of Columbus, He Praised the Pope and Pointed Up His Antiabortion Stance, Philadelphia InQuirer, Aug. 4, 2004, at A10.

252. Id. Such statements call into question Bush's respect for the separation of church and state. It is ironic that when John Kennedy ran for president in 1960 he had to distance himself from the Roman Catholic Church, while during the 2004 presidential election, Bush tried to get as close as he could to the Catholic Church, apparently without much criticism from the mainline media.

Support for Bush tends to fall along the lines of those who strongly support religion, who "see him as one of them when he speaks of Christ's power to change hearts," and those who do not, and who believe that Bush's "religious language strikes many as presumptuous and divisive." Dickerson \& Tumulty, supra note 244 .

Conservative religious groups, from the late 1970's until today, have tried to influence public policy and have influenced Republicans presidents from Reagan to Bush. Mitch Frank, Church and Statesmen, Time, Mar. 13, 2000, at 32. Such groups includes Jerry Falwell's Moral Majority, Pat Robertson's and Ralph Reed's Christian Coalition. See id. These groups have had only moderate success. See id. Their biggest hope from changing the moral fiber of this country occurred when Newt Gingrich and other Republicans seized control of Congress; however, some of the conservative religious leaders who supported them became disillusioned when these republican leaders were not successful in obtaining the types of legislative victories that the religious leaders wanted them to achieve. See id.

253. Nigel Hunt, Iraq War Weakens Bond Between Bush, Evangelicals, May 18, 2004, available at http://www.commondreams.org/headlines04/0518-06.htm. In addition to the Roman Catholic leaders, evangelicals, who represent twenty-five to thirty percent of those who voted in the 2000 presidential election, have much clout with President Bush and the Republican Party, and they want to interject their religious view into the debate of public policy issues. See id. 
Presently, there appears to be more of an impetus for President Bush and other politicians to interject their religious beliefs into political debate on public policy issues, given that the American electorate appears to be almost evenly divided between Democrats and Republicans. ${ }^{254}$ The almost equal division of the populace between the two major political parties means that both parties must court religious groups if they want to improve their chance of winning elections. ${ }^{255}$ The Republican Party's fate and President Bush's fate, in the 2004 Presidential Election, depended upon their ability to maintain the support and the votes of such religious groups. ${ }^{256}$ One commentator stated the following regarding President Bush:

[T] his president - this presidency — is the most resolutely "faith-based" in modern times, an enterprise founded, supported and guided by trust in the temporal and spiritual power of God. Money matters, as does military might. But the Bush administration is dedicated to the idea that there is an answer to societal problems here and to terrorism abroad: give everyone, everywhere, the freedom to find God, too. ${ }^{257}$

Some believe that President Bush's reliance upon his faith opens him to important criticisms. ${ }^{258}$ His faith leads to a certain stubbornness where, without having given appropriate consideration to opposing viewpoints, President Bush will make those public policy decisions that he believes God wants him to make. ${ }^{259}$ This is what some believe occurred when he made the decision to invade Iraq. ${ }^{260}$ Apparently, the President believes that his faith gives him "a very clear sense of what is good and what is evil." 261 In addition

254. See Liz Marlantes, A Deepening Divide Between Red and Blue, The Christian Science Monitor (Boston, Ma.), Nov. 4, 2004, at 1.

255. See id.

256. Howard Fineman et al., Bush and God; A Higher Calling: It is His Defining Journey from Reveler to Revelation. A Biography of His Faith, and How He Wields it as He Leads a Nation on the Brink of War, Newsweek, Mar. 10, 2003, at 22, available at http://people.cas.sc.edu/rosati/ fineman.god.newsweek.303.htm.

257. See id.

258. $I d$.

259. $I d$.

260. See id. One commentator states that Bush's religious base is "by far the strongest supporters of a war-unilateral if need be - to remove Saddam." Id.

261. Id. One commentator says the following about Bush's use of his faith:

Aides say the president's quiet but fervent Christian faith gives him strength but does not dictate policy. He's only seemed like preacher in chief, they say, because of what one called "a confluence of events": the September 11 terror attacks, the terror alerts, and the Columbia shuttle explosion. Still, belief gives him something more than confidence, says his closest friend, Commerce Secretary Don Evans: "It gives him a desire to serve others and a very clear sense of what is good and what is evil." 
to believing that he was "called" by God "to seek higher office," the President might not listen to sound advice from other political leaders even when such leaders might have more experience and wisdom than the President. ${ }^{262}$ For example, instead of asking his father, a former president, for advice before invading Iraq, President Bush says that he sought advice from "a higher father." ${ }^{263}$ The President picks a course of action that he believes is the will of God and sticks with it and hopes that everything will turn out for the best because God is in charge of everything. ${ }^{264}$ This manner of resolving public policy issues frequently means that the President's decisions are not sufficiently vetted by other humans who might have opposing opinions. ${ }^{265}$

In light of President Bush's strong commitment to religious beliefs, his courting of religious groups, and his August 9, 2001 statement of the reasons for his ban on embryonic stem cell research, it seems reasonably clear that his ban was motivated by a religious belief in the sanctity of life at all development stages, a religious belief that the Roman Catholic Church and other religious organizations advocate.

Id.

262. $I d$.

263. William Hamilton, Bush Began to Plan War Three Months After 9/11, WAsH. Post, Apr. 17, 2004, at A1, available at http://www.washingtonpost.com/wp-dyn/articles/A17347-2004Apr16.html.

264. Id. One commentator states: "Still, faith helps Bush pick a course and not look back. He talks regularly to pastors, and loves to hear that people are praying for him. ... Now there is a sense of destiny that approaches the Calvinistic. 'There is a fatalistic element,' said David Frum, the author and former Bush speechwriter. 'You do your best and accept that everything is in God's hands.' The result is unflappability. 'If you are confident that there is a God that rules the world,' said Frum '. . . you do your best, and things will work out.' But what some see as solidity, others view as a flammable mix of stubbornness and arrogance. 'No one's allowed to second-guess, even when you should,' said another former staffer." Fineman, supra note 256.

265. Fineman, supra note 256. Regarding the war against Iraq, some religious leaders supported Bush's efforts, while others, like the pope, "the National Council of Churches, [and] many Jewish groups," despite such groups' respect for Bush's faith, did not support the war. See id. Apparently, those religions in the opposition "wonder if [Bush] is ignoring nuances in what sounds like a messianic mission." Id.

The second criticism is that President Bush will allow his religious beliefs, and the evangelicals' beliefs, dictate the public policy decisions that he makes. See id. Some believe that Bush has donejust that when he has sought to appoint conservative judges some of whom oppose Roe v. Wade, ban stem cell research and human cloning; ban partial-birth abortions; institute his faith-based initiatives where the federal government gives churches fund ing for the churches' social programs; and fund programs that teach abstinence in public school. See id. It is Bush's decisions in these area that pose a serious conflict with the First Amendment's anti-federal establishment and promotion of religion, as will be argued below. 


\section{Conclusion}

In the final analysis, the problem is not that President Bush has courted votes from the evangelicals and Roman Catholics, as even President Bill Clinton was interested in religion both before and after his presidency. ${ }^{266}$ However, the difference between President Bush and President Clinton is that, although President Clinton met with, and sought advice and prayers from religious leaders throughout his eight-year presidency, including from evangelicals, President Clinton did not allow his personal beliefs to influence his decisions on public policy issues, at least not to the extent that President Bush apparently has. For example, President Clinton continued his support of a woman's right to an abortion and gay rights, despite evangelical opposition. ${ }^{267}$ Furthermore, in opposition to the wishes of many religious groups, President Clinton issued executive orders ending President Reagan's and the first President Bush's ban on fetal-tissue research, abolishing the socalled Mexico City rule, which prohibited federal aid to international planning agencies that were in any way involved in abortions; and reversing the Bush "gag rule" barring abortion counseling at family planning clinics that receive federal funds. ${ }^{268}$

Regardless of what else one might say about President Clinton, no one can say that he allowed his faith to dictate his federal policy decisions. ${ }^{269}$ This Article asserts that his resistance against pressures from the religious right on the abortion and gay rights issues was a proper reconciliation of how religious groups should be treated on issues involving federal policy in light of the First Amendment's separation of church and state; such groups should be listened to but their religious opinions based on religious doctrines and beliefs should not become public policy for America's secular society, unless proponents of challenged laws can meet the mixed motive test that this Article offers. The Supreme Court should calibrate its religious purpose doctrine jurisprudence to ensure this proper balance. The adoption of the mixed motive, burden of proof shifting proposal that this Article offers would be a step in the right his life).

266. William J. Clinton, My Life 250-52 (2004) (discussing how the Pentecostal faith influenced

267. See id. at 465 .

268. Id. at 481-82.

269. Although one might argue that Clinton had questionable morals, given his relationship with Monica Lewinskey, it would be difficult to argue that such alleged questionable morals denied potential beneficial medical treatments, such as embryonic stem cell research, to American citizens. Such a denial might now occur in light of President Bush's ban on the federal funding of future lines of embryonic stem cell research. 
direction. When applied to President Bush's ban on federal funding of future lines of embryonic stem cell research, the conclusion should be that the ban violates the Establishment Clause. At a minimum, the proponents of the ban should be required to prove by a preponderance of the evidence that President Bush would have imposed the ban even if he had not allowed his religious beliefs to motivate his decision to ban the funding of this type of research. 